\title{
Paleozoic rocks structure versus Cenozoic cuesta relief along the Baltic Shield-East European Platform transect
}

\author{
Igor TUULING ${ }^{1, *}$ \\ 1 University of Tartu, Institute of Ecology and Earth Sciences, Ravila 14A, 50411 Tartu, Estonia
}

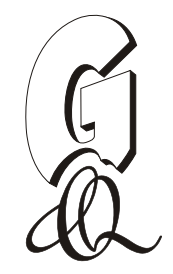

Tuuling, I., 2017. Paleozoic rocks structure versus Cenozoic cuesta relief along the Baltic Shield-East European Platform transect. Geological Quarterly, 61 (2): 396-412, doi: 10.7306/gq.1342

\begin{abstract}
Based on structural maps, the bedrock structure on the southern slope of the Baltic Shield is analysed. Gently southerly dipping $\left(0.1-0.2^{\circ}\right)$ Paleozoic layers from Estonia to the Swedish east coast form the Baltic Homocline (BH). Numerous monoclinal folds, forced by basement faulting, induce slight variations in bedrock attitude across the $\mathrm{BH}$. Studies on faults exposed in Southern Finland suggest that many monoclinal folds inducing basement faults within the BH are of Precambrian origin and have been active in pulses. The present monoclines were shaped by the Caledonian Orogeny. Submeridional tectonic hinge-lines induce minor regional-scale changes in the structural setting and control trends/styles of the forced folds. From the west, the $\mathrm{BH}$ bounds with the Baltic-Bothnian mobile zone that has been intermittently active since Mesoproterozoic times. The evolving Baltic Syneclise in the Silurian rearranged the structural setting typical for the Ordovician Baltic Basin. The Cenozoic uplift of Scandinavia created a SE-to-E-dipping bedrock sequence around the Gotland-Öland area. As the latter area had a different attitude than the BH, two Cenozoic cuesta-sets started to evolve around the northern Baltic Proper. They both had an outlet to the N-S-flowing Eridanos River around the Gotska Sandön area, creating thus two independent sections of the Baltic Klint.
\end{abstract}

Key words: Baltic Homocline, intracratonic forced folds, Estonia, Swedish east coast, Cenozoic cuesta relief, Baltic Klint.

\section{INTRODUCTION}

Cambrian dikes preserved in the basement fissures (Martinsson, 1956), Paleozoic outliers in tectonic grabens/depressions or impact craters (Puura et al., 1996; Puura and Plado, 2005), as well as altered Lower Cambrian clay minerals and acritarchs (Hagenfeldt, 1997; Kirsimäe et al., 1999) reveal that the Baltic Shield region in the East European Craton interior was once covered by a much thicker Vendian to Devonian rocks that extended further north. In accordance with the regional tectonic development and structural setting, a great amount of Early Paleozoic rocks have been removed from the Baltic Shield area. Presently, a cuesta-type terraced relief, eroded into the Cambrian-Silurian layers, extends along the Baltic Shield-East European Platform contact from Estonia across the central Baltic Sea, and continues along the east coast of Sweden (Tuuling and Flodén, 2016).

The platform cover in the northwestern corner of the East European Platform consists largely of Lower Paleozoic rocks. Exposed from the Lake Ladoga district in NW Russia to the Estonian west coast and hidden below the Baltic Sea, the Cambrian-Silurian sequences emerge again on the islands of

\section{*E-mail: igor.tuuling@ut.ee}

Received: September 5, 2016; accepted: December 7, 2016; first published online: January 24, 2017
Gotland and Öland off the Swedish east coast (Fig. 1). Although the distribution of coeval rocks across the central Baltic Sea has already been resolved in the mid-1800s (Murchison, 1844; Schmidt, 1859; see Tuuling and Flodén, 2009a), their exact geological/structural relations have remained largely unclear for about a century. Only the boreholes drilled in the 1940-1950s in the Baltic countries, Russia, Poland and Sweden (e.g., Martinsson, 1958; Männil, 1966; Kaljo, 1970) cemented the idea of a unique Palaeobaltic Ordovician-Silurian basin.

The boreholes have shown that the area of Estonia was situated in the shallowest part of this S-SE-ward deepening ba$\sin$. Thus, the Ordovician and Silurian sequences exposed respectively on Öland and Gotland represent deeper facies varieties of the rocks seen in Estonia (Männil, 1966; Kaljo, 1970, 1977; Jaanusson, 1976; Jeppsson et al., 1994; Nestor and Einasto, 1997). However, almost no attention has been paid to the fact that the current structural setting of the Paleozoic sequence along the Swedish east coast contradicts the conception of a joint, southwestward deepening Ordovician-Silurian basin extending from Estonia across Scandinavia. Namely, a much deeper limestone facies around Gotland-Öland occurs presently at the same or even higher elevation as coeval shallow-marine rocks in Estonia. Furthermore, their southeasterly to easterly tilt opposes the general south to southwesterly deepening facies trend in this basin. Hence, the primary structural setting of the Ordovician-Silurian layers exposed along the Swedish east coast has had considerable changes.

Extensive seismic profiling since the early 1960s has resulted in a huge amount of data about the distribution, thick- 


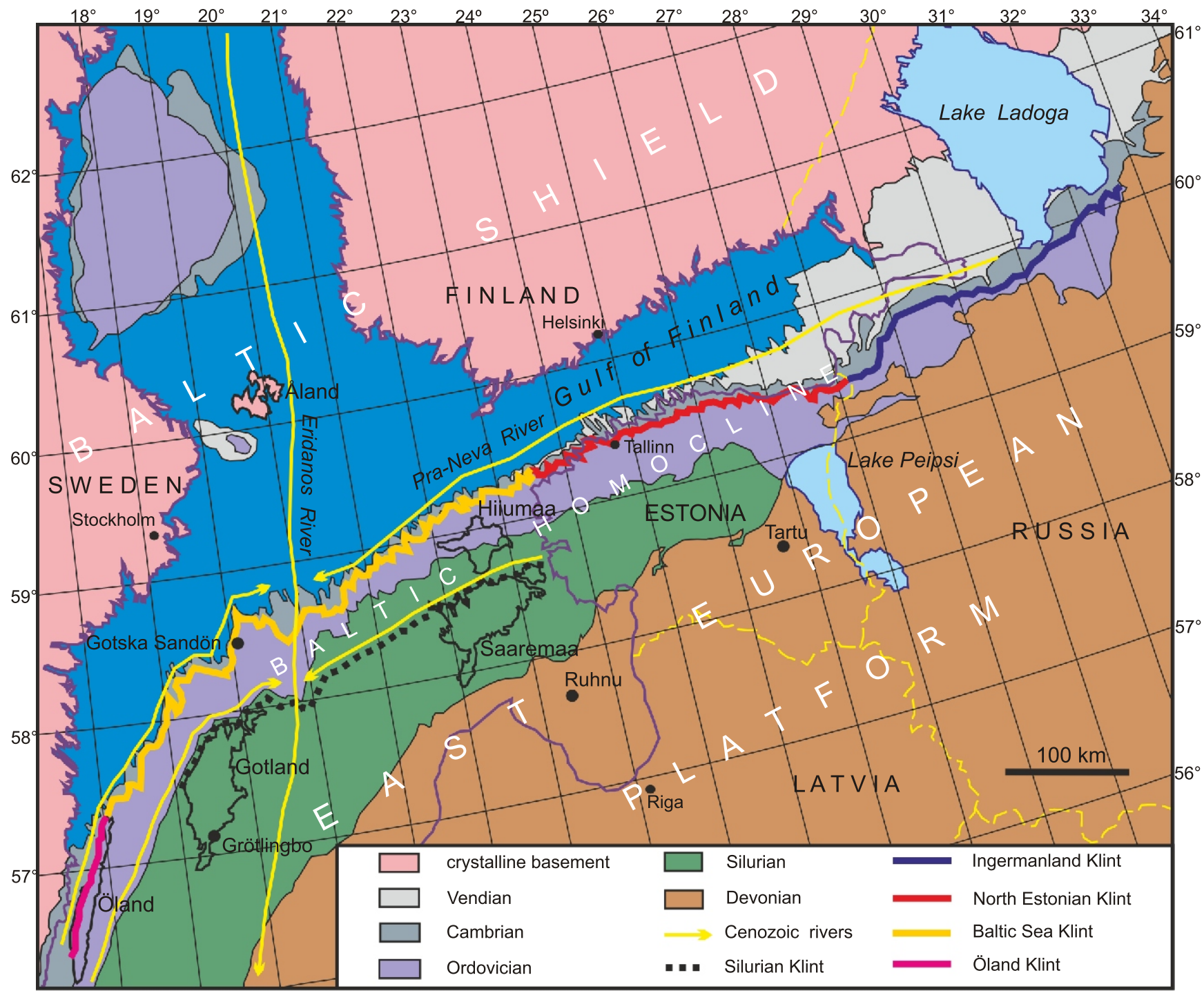

Fig. 1. Regional geological-structural setting with a supposed Cenozoic river system that shaped the cuesta-type relief and klint escarpments along the Baltic Shield-East European Platform transect

nesses, and thus structure of different Paleozoic layers beneath the central Baltic Sea (Flodén, 1975, 1980; Flodén et al., 1994, 2001; Tuuling et al., 1995, 1997; Tuuling and Flodén 2000a, 2001, 2007, 2009a, b, 2011, 2013). Fusing this information with the surrounding mainland knowledge, this paper aims to generalise the structure of the platform sedimentary cover on the southern slope of the Baltic Shield, and to analyse its changes/trends from Estonia to the Swedish east coast. In the light of this generalization, the history of structural rearrangements of the Paleozoic rocks along the eastern Swedish coast, i.e. in the Gotland-Öland area and development of a terraced Cenozoic bedrock relief at the shield-platform transect are discussed.

\section{GENERAL GEOLOGICAL-STRUCTURAL SETTING}

FORMATION AND EXTENSION OF THE ORDOVICIAN-SILURIAN SEQUENCE

The platform veneer on the southern slope of the Baltic Shield and along the Swedish east coast varies in age from
Neoproterozoic (Vendian) to Devonian (Fig. 1). However, facies and thickness trends along with palaeontological data and patchy bedrock outliers in Norway, Sweden and Gulf of Bothnia etc. reveal that a unique sedimentary basin spreading across wide areas of Baltoscandia existed only during the Ordovician-Silurian periods (Männil, 1966; Jaanusson, 1976; Owen et al., 1990; Kaljo et al., 1991; Baarli, 2003).

The history across the western margin of the Baltica continent stretching and towards the lapetus Ocean in the west and the Tornquist Sea in the south-west opening Baltoscandian Ordovician-Silurian basin (Torsvik and Cocks, 2013) was largely controlled by the ongoing Caledonian Orogeny. Thus, the gently sloping and remote continental hinterlands reaching epicontinental Ordovician sea shrank gradually to a pericontinental basin with a sharply differentiated bathymetry towards the Silurian period (Nestor and Einasto, 1997; Tuuling and Flodén, 2009b, 2011). The progressively closing and colliding Baltica, Laurentia and Avalonia continents (Torsvik and Rehnstöm, 2003; Torsvik et al., 2012) induced the formation of a large basement depression, i.e. the Baltic Syneclise further south of the Baltic Shield. A new, elongate tongue-like depocentre, the so 
called Livonain Tonque with a more complex and rapidly changing facies zonation evolved from the present southern Baltic Sea towards Estonia (Jaanusson, 1973).

As a result, the Ordovician sequence with $\mathrm{N}-\mathrm{S}$ deepening facies/rock units described in Estonia extends to the Swedish east coast. It can be easily followed in the seismic lines across the central Baltic Sea (Flodén et al., 1994; Tuuling and Flodén, 2009a) and is ascertained between the Swedish islands of Gotska Sandön and Öland (Grahn and Nölvak, 2010). However, the more clayey and complete Silurian succession on Gotland represents a significantly deeper basinal section compared to that on Saaremaa. Thus, the Silurian sequences, directly incomparable across the Baltic Sea in terms of facies and lithology, can be correlated based only on detailed micropalaeontological studies (Jeppsson et al., 1994). The seismic correlation of the Silurian sequence across the Baltic Sea, however, is highly tentative. Besides the variable and rapidly changing lithology, the continuity of the seafloor-forming Silurian rocks is dismembered by numerous smaller or larger erosional cuts (Tuuling and Flodén, 2009a, b, 2011, 2013, 2016).

THE SUB-VENDIAN/CAMBRIAN PENEPLAIN AND THE BALTIC HOMOCLINE

Seismic studies have proved that the general tectonic setting alongside the platform Precambrian basement and Paleozoic veneer relations described in Estonia (Puura and Vaher, 1997) continues below the central Baltic Sea area (Tuuling and Flodén, 2001). Thus, at a gentle angle (6-13') under the platform cover, the southern slope of the Baltic Shield forms an extensive peneplain that is eroded into Precambrian crystalline rocks (Winterhalter et al., 1981; Puura et al., 1996, 1999).

In most of Estonia and the central Baltic Sea, this peneplain has normally a southerly tilt $\left(175-182^{\circ}\right)$, which, however, deviates along its flanks clearly to the south-east (see Winterhalter et al., 1981: fig. 1.16; Sildvee and Vaher, 1995: fig. 5). Thus, the tilt azimuth of $164-167^{\circ}$ around the Estonian/Russian border turns to about $148^{\circ}$ some $10 \mathrm{~s} \mathrm{~km}$ further east (Puura and Mardla, 1972; Tuuling, 1988). Structure contours of the sub-Cambrian surface along the Swedish east coast (Flodén, 1975: fig. 10) reveal that its tilt trend changes considerably around northern Gotland. Thus, being about $160-165^{\circ}$ and $130-135^{\circ}$, respectively, north-east and north-west of Gotland, the tilt azimuth of the basement surface attains a nearly easterly trend around the island of Öland further south (Flodén, 1980).

The recumbent bedrock layers largely conform to, and thus follow, this peneplained crystalline basement surface. This slightly S-SE-sloping Early Paleozoic sequence was east of the Baltic Sea, distinguished as the Estonian Homocline (Puura and Vaher, 1997). The analogous structure across the entire southern slope of the Baltic Shield from NW Russia to the northern Gotland area, however, is the Baltic Homocline $(\mathrm{BH}$ : Tuuling and Flodén, 2001, 2016; Fig. 1).

The southern limit of the $\mathrm{BH}$, drawn provisionally along the $-550 \mathrm{~m}$ structure contour of the crystalline basement surface (Puura and Vaher, 1997), stretches from southern Estonia across the central Baltic Sea to the northern Gotland area (see Winterhalter et al., 1981: fig. 1.16). On the Estonian mainland, this boundary coincides structurally largely with the northeastern section of an extensive tectonic activity zone, the so-called Liepaja-Riga-Pskov fault zone, where the basement surface can along deep basement faults occasionally fall where the basement surface can along deep basement faults occasionally fall up to $700 \mathrm{~m}$ (Brio et al., 1981; Puura and Vaher, 1997). However, no major structural changes have been revealed along this boundary, either around southern Saaremaa or be- low the Baltic Sea, where the BH passes smoothly into the Baltic Syneclise.

Following the Precambrian peneplain, the overlying platform cover along the Swedish east coast has, compared to the $\mathrm{BH}$, a clearly different structural setting with a regularly changing attitude of the Paleozoic layers from the northern Gotland towards the island of Öland. Although there are many studies discussing various tectonic aspects along the Swedish east coast (e.g., Flodén, 1975, 1980; Puura and Flodén, 1997; All et al., 2006), the structural transition from the $\mathrm{BH}$ to the Swedish east coast, as well as the general bedrock structure around the Gotland-Öland area have been so far very poorly discussed. Both these topics concern the main goal of this paper and will be treated in more detail below.

\section{AVAILABLE AND ANALYSED DATA}

The structure of the $\mathrm{BH}$ discussed below is largely based on earlier published structure contour maps. Based on tens of thousands of prospecting/mapping drilling records onshore, the structural trends with the attitude of the Paleozoic sequence, as well as the style and characteristics of tectonic deformations are well-contoured and described in Estonia (Puura and Vaher, 1997; Fig. 2). A similar structural map based on continuous seismic reflection profiling was compiled for the central Baltic Sea area (Tuuling and Flodén, 2001; Fig. 3). To evaluate the attitude and general structural trends of the Paleozoic sequence along the Swedish east coast and to describe its structural contact with the $\mathrm{BH}$, a novel structure contour map was drawn for this study (Fig. 4), combining rare drilling data scattered across isolated islands (Hedström, 1923; Thorslund and Westergård, 1938; Westergírd, 1944, 1947; Thorslund, 1958; unpublished OPAB and SGU cores) with continuous seismic reflection profiling results of Flodén (1980).

\section{TECTONIC DEFORMATION AND E-W STRUCTURAL CHANGES OF THE BALTIC HOMOCLINE}

\section{LINEAR ZONES OF DISTURBANCE}

In general, the $\mathrm{BH}$ as a continental interior structure is tectonically slightly disturbed. However, attitude variations in the Paleozoic sequence occur because of the so-called linear zones of disturbances (LZD) that divide the 100-500 m thick platform veneer structurally into separate blocks (Puura and Vaher, 1997; Tuuling and Flodén, 2001). Having the roots in basement faults, these usually $1-4 \mathrm{~km}$ wide and 20-60 km long flexural bends in the platform cover with occasional small faults, folds and heavily fractured/crushed rocks induce discernible structure contour displacements (Figs. 2, 3 and 5). The offset of the layers between the blocks, remaining usually within the limits of a couple of $10 \mathrm{~s} \mathrm{~m}$, may at larger LZD reach up to $50 \mathrm{~m}$ (Puura and Suuroja, 1984; Puura and Vaher, 1997).

Since mostly sub-meridionally oriented LZD traverse the sub-parallel strike of the southerly sloping homocline (Figs. 2 and 3), the tilt azimuth of the bedrock layers within these zones can occasionally attain a nearly easterly or westerly trend. The highest inclination of the layers (up to $18^{\circ}$ ) was measured in the centre of the Ahtme LZD (Kattai and Vingisaar, 1980: fig. 4). However, besides causing slight attitude variations of the Paleozoic layers across the $\mathrm{BH}$, in a few places, a single or a group of LZD can form a tectonically active zone that brings about mi- 


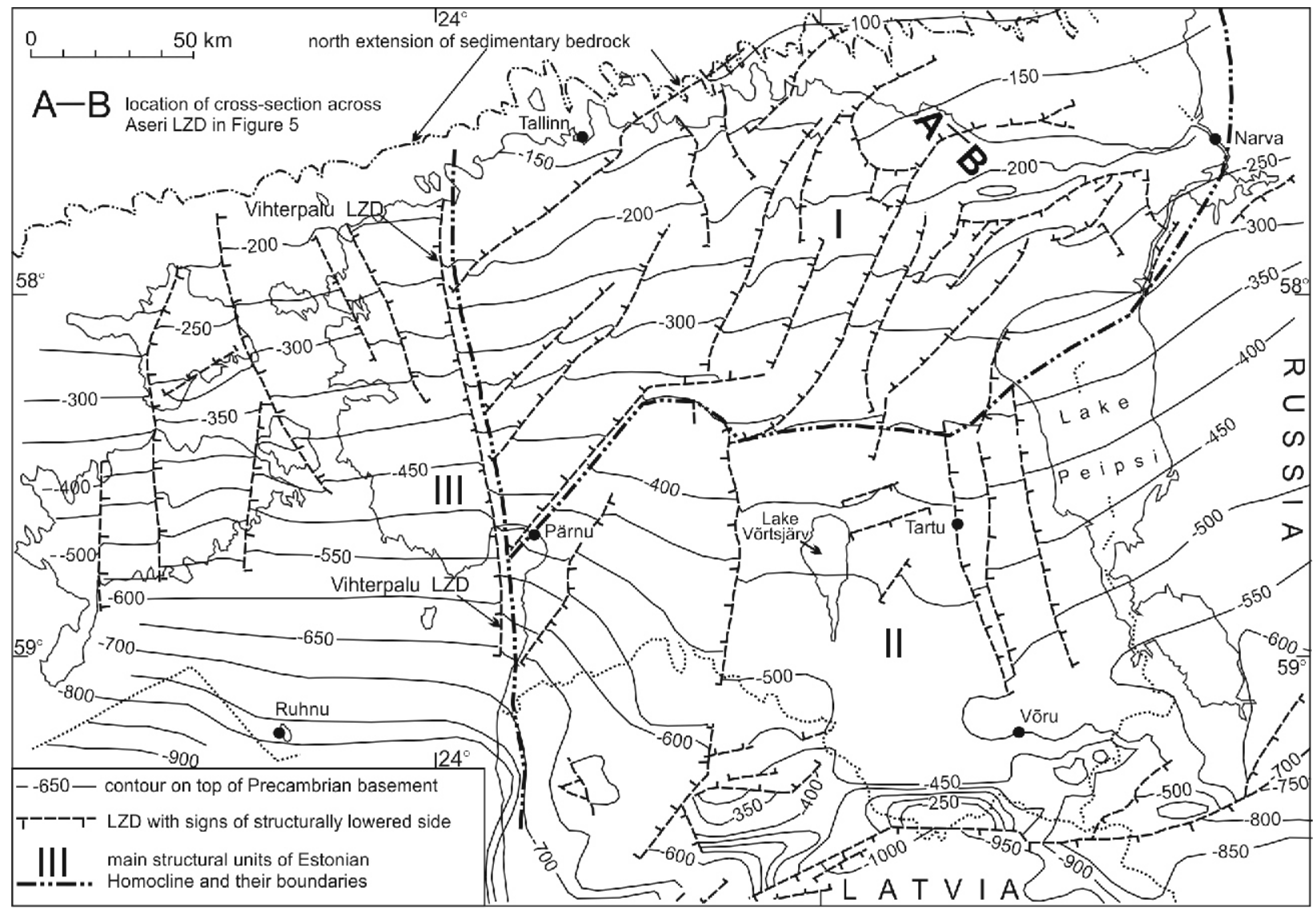

Fig. 2. Structure contour map of the platform cover of Estonia with various sets of LZD,

which enable main structural subdivisions of the Estonian Homocline (modified after Puura and Vaher, 1997)

I - North Estonian segment, II - Northeastern Estonia Pärnu zone, III - West Estonian part

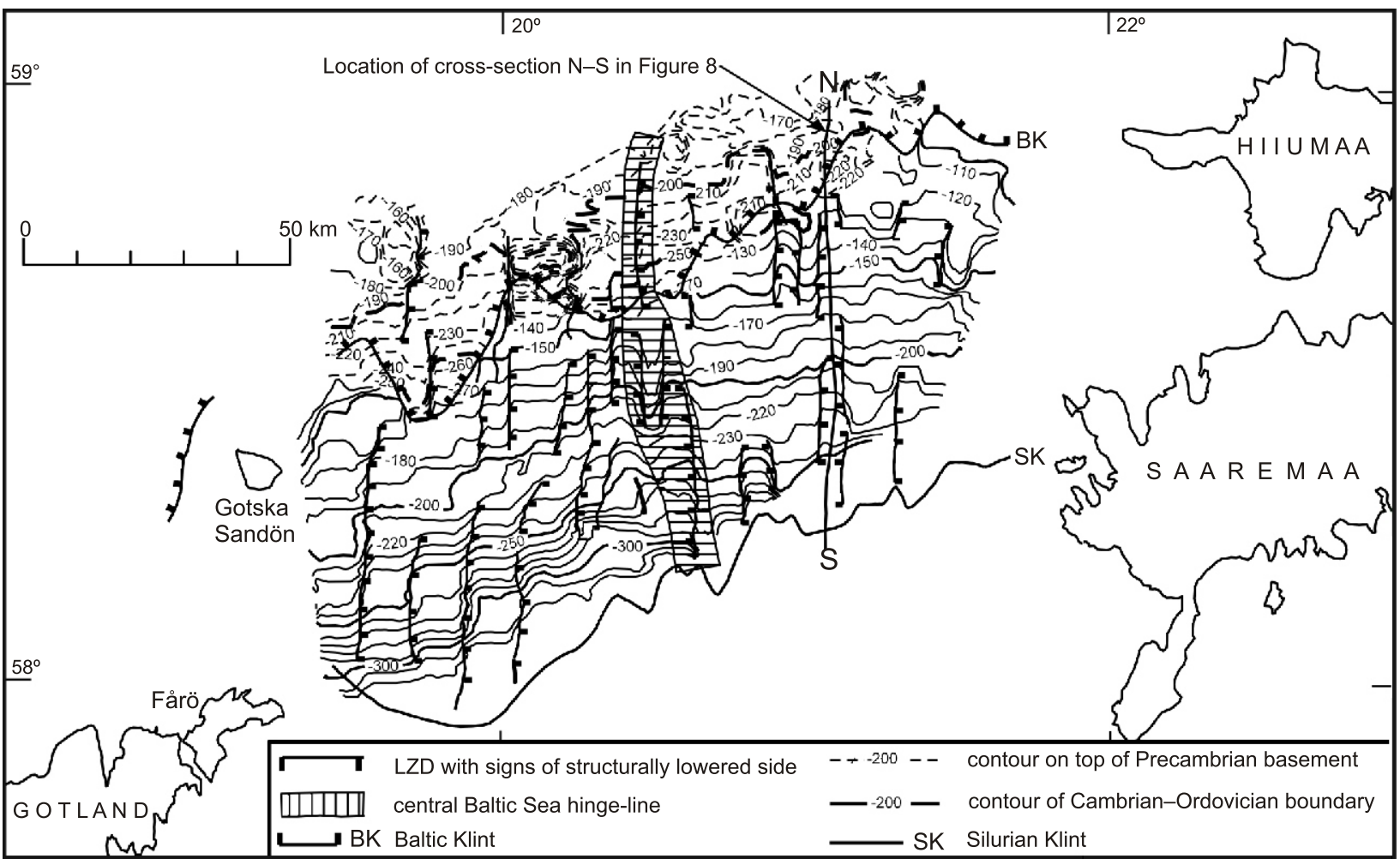

Fig. 3. Structure contour map of the Paleozoic rocks beneath the central Baltic Sea (modified after Tuuling and Flodén, 2001) 


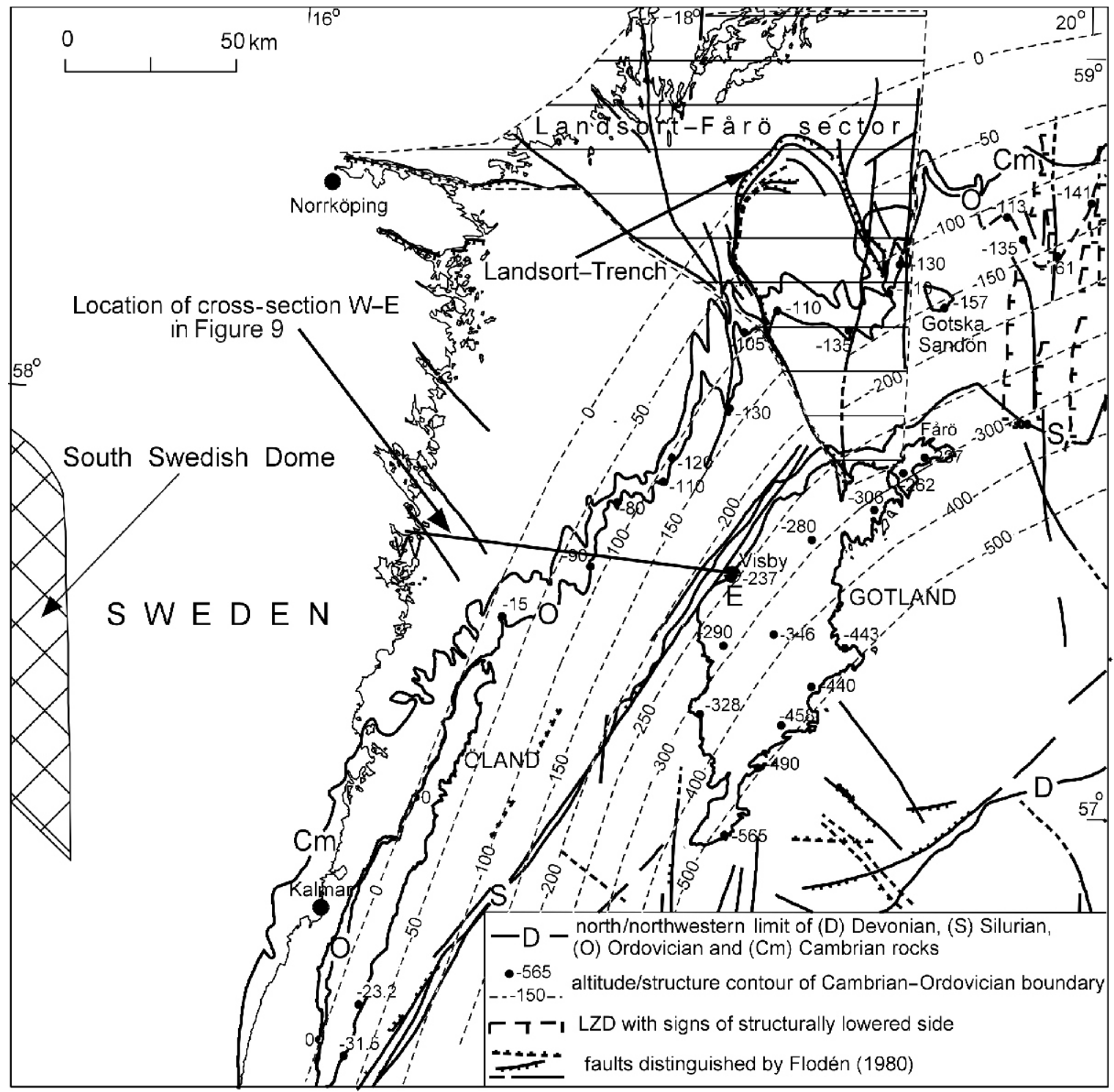

Fig. 4. Structure contour map of the Paleozoic rocks with the main tectonic lineaments along the Swedish east coast between Gotska Sandön and Öland

nor regional-scale changes in the structural setting. These, traversing meridionally the $\mathrm{BH}$ zones with increased tectonic activity, appear as some sort of structural hinge-lines on the southern slope of the Baltic Shield. Besides modifying the attitude of the bedrock layers, these hinge-lines also clearly control the trend and style of the LZD across the $\mathrm{BH}$.

\section{STRUCTURE OF THE ESTONIAN HOMOCLINE}

The details of the structural map (Fig. 2) are, due to extensive oil-shale and phosphorite prospecting, much greater in northeastern Estonia. For the remainder of the territory, however, the frequency of boreholes enables only larger deformations to be seen, which control the general structural trends of the platform cover.

Excluding the highly deformed rocks near the Liepaja-Riga-Pskov fault zone, the platform cover in Estonia can be structurally divided into three areas (I, II and III in Fig. 2) based on the general attitude of the Paleozoic layers and the style and orientation of the LZD. First, the largest known Vihterpalu LZD ( $~ 8 \mathrm{~km}$ wide, $>150 \mathrm{~km}$ long, and with $\sim 50 \mathrm{~m}$ off- set) is a tectonic hinge-line that dissects the Estonian Homocline into the western and eastern parts (Fig. 2). The significantly wider eastern part is divided into: (1) the North Estonian segment; (2) from the Narva district across Lake Peipsi to the Pärnu bending zone, which separates the North Estonian segment from the Liepaja-Riga-Pskov fault zone (Fig. 2).

The North Estonian segment. The North Estonian segment between the Vihterpalu LZD and the northeasternmost corner of Estonia (I in Fig. 2) is characterized by a uniform attitude of the bedrock layers and a stable architecture of the LZD. Thus, the $\sim 6-10^{\prime}$ southerly dipping (tilt azimuth $\sim 178-182^{\circ}$ ) Paleozoic sequence is dissected by the LZD having a largely northeasterly trend $\left(30-40^{\circ}\right)$ and structurally lowered northwestern sides. A weak deviation of the tilt trend towards the south-east $\left(175^{\circ}\right)$ occurs near the Vihterpalu LZD (Fig. 2).

Northeastern Estonia-Pärnu zone. This zone (II in Fig. 2) is characterized around the North Estonian segment by the changing style and orientation of the LZD, which is accompanied by a gradual SE-SW-turning tilt azimuth of the Paleozoic layers. Three distinctive sections appear from the NE to SW: 
NW

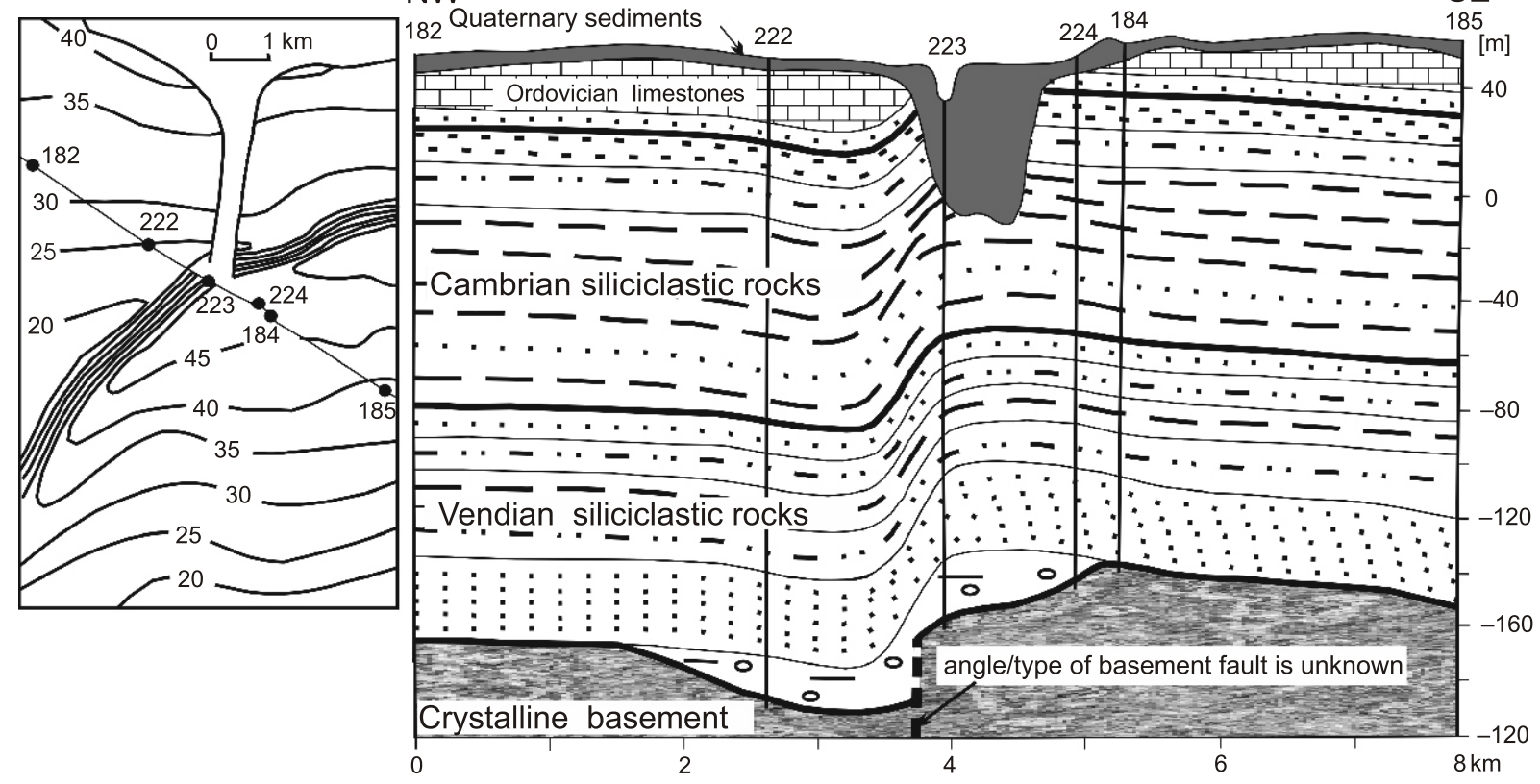

SE

Fig. 5. Modified after Puura and Vaher (1997) geological cross-section across the Aseri LZD

(with a detailed excerpt of the structure contour map of the platform cover) showing the monoclonal forced fold above the basement fault (location see Fig. 2)

1. A typical section for the eastern flank of the $\mathrm{BH}$ with a southeasterly tilt azimuth $\left(160-168^{\circ}\right)$ of the bedrock layers, which bends and widens from northeasternmost Estonia across Lake Peipsi southwestwards (Fig. 2). Around the northern part of the lake, this segment reveals a few curvilinear LZD with a northeasterly trend $\left(50-60^{\circ}\right)$ and mostly with structurally lowered southeastern sides. However, the western margin of this segment, some $30-40 \mathrm{~km}$ west of Lake Peipsi, is traversed by a group of three LZD with a slight northwesterly trend $\left(345-350^{\circ}\right)$ and structurally lowered eastern sides (Fig. 2).

2. The latter group of dislocations is followed by a 70-80 km wide, across central-southern Estonia stretching section (the Vörtsjärve block) with southerly tilted Paleozoic layers. This slightly uplifted block is terminated from the west by an extensive sub-meridional LZD with a structurally lowered western side (Fig. 2).

3. Between the latter section and the Vihterpalu LZD, a bedrock block has a southwesterly tilt azimuth $\left(200-210^{\circ}\right)$ that is exceptional for Estonia. A LZD within this section has, similar to the North Estonian section, a northeasterly trend $\left(40-50^{\circ}\right)$, with a structurally lowered southeastern side (Fig. 2).

West Estonian part. Similar to the North Estonian segment, southward dipping Paleozoic layers dominate in the West Estonian part of the Estonian Homocline (III in Fig. 2). However, unlike the latter segment, the LZD here have either a sub-meridional or a slight northwesterly $\left(340-345^{\circ}\right)$ trend and mostly structurally lowered eastern/northeastern sides. The latter trend starts with the tectonic hinge-line (Vihterpalu LZD) and is confined within a 50-75 km wide area west of it. The NW-ward trending LZD may have both, i.e. either northeastern or southwestern side structurally lowered. The area with $\mathrm{N}-\mathrm{S}$-trending LZD and structurally lowered eastern sides covers the West Estonian islands further west (Fig. 2).
In all, these northwesterly trending LZD induce a structurally lowered wedge between the Vihterpalu LZD and the Saaremaa-Hiiumaa islands, which is distinguished from the surrounding areas by its distinctive southeasterly $\left(175^{\circ}\right)$ tilt of the bedrock layers. Within this wedge, a pair of LZD with structurally lowered opposite sides delineates a narrow horst-like structure (Fig. 2).

\section{BEDROCK STRUCTURE BENEATH THE CENTRAL BALTIC SEA}

Regarding the number and style of the LZD with the attitude of the bedrock layers, a tectonic hinge-line midway the Baltic Sea divides the submarine $\mathrm{BH}$ into the eastern and western halves (Tuuling and Flodén, 2001; Fig. 3). This, modifying the structural setting and attitude of the bedrock hinge-line, splits into three sections. Thus, the LZD with structurally lowered eastern and western flanks, respectively in its northern and southern parts, is separated by a horst-like elevation induced by a pair of LZD with structurally lowered opposite sides.

Eastern part of the central Baltic Sea. The bedrock structure typical for the West Estonian islands, i.e. a slight (7') southerly $\left(175-180^{\circ}\right)$ tilt of the Paleozoic layers with sub-meridional LZD, continues within the eastern half of the central Baltic Sea (Fig. 3). However, unlike the West Estonian part, structural lowering of the rocks occurs here equally often along the western flanks of LZD. In many places, two closely spaced LZD with structurally lowered opposite sides form either uplifted horst- or down-faulted graben-like structures.

Western part of the central Baltic Sea. Compared to the eastern half, the number of the sub-meridional LZD in the western half of the submarine Baltic Homocline, particularly just north-east of Fårö, increases noticeably (Figs. 3 and 4). As they all have their western flanks structurally elevated, the tilt azimuth of the Baltic Homocline starts here to deviate gradually southeastwards and reaches $\sim 155-160^{\circ}$ just NE of Gotland. Furthermore, this azimuth change is accompanied by an inclination increase of the bedrock layers. Thus, an inclination of 
4.2' north-east and east of Gotska Sandön, doubles southeastwards and reaches $\sim 8.5$ ' north-east of Gotland.

\section{STRUCTURE OF SEDIMENTARY BEDROCK ALONG THE EASTERN SWEDISH COAST}

Because of the rare and scattered boreholes between solitary islands, available data for estimating the structure of the Paleozoic sequence along the Swedish east coast are scarce. Thus, regarding the attitude, usually only a gentle southeasterly tilt of the Paleozoic layers on Gotland (e.g., Munthe et al., 1925; Hede, 1960) or an east to southeastward tilt on Öland (e.g., Stouge, 2004; Grahn and Nölvak, 2010) are mentioned. The tilt of the Silurian layers, if mentioned, is estimated roughly to be $<1^{\circ}$ (e.g., Munnecke et al., 2000; Calner et al., 2004). However, according to the most recent assessments (Erlström et al., 2009), this angle on Gotland remains between $0.2-0.4^{\circ}$. A very rough inclination of the Ordovician layers, i.e. $<2^{\circ}$, has been pointed out on Öland (Grahn and Nőlvak, 2010).

\section{STRUCTURAL MAP ALONG THE SWEDISH EAST COAST}

To assess the attitude and general structural trends of the Paleozoic rocks along the Swedish east coast, a structural map was compiled by combining appropriate drilling and marine seismic data around the Swedish islands of Gotska Sandön, Fårö, Gotland and Öland (Fig. 4). To obtain the best reliability between the onshore and offshore data and to maximise structure contouring data points offshore, the Cambrian-Ordovician boundary was chosen as the most informative structural surface. This surface, coinciding largely with the contact of terrigenous and calcareous rocks (Tuuling and Flodén, 2009a; Nielsen and Schovsbo, 2011), is easily recognizable as a strong seismic reflector $\left(\mathrm{O}_{1}\right)$ just below the rim of the submarine Baltic Klint (Tuuling and Flodén, 2016), and can be firmly fixed even in the boreholes when no core was taken. Furthermore, this level enables the structural transition and changes from the central Baltic Sea area to be followed directly towards the Swedish east coast; its emergence above the sea can be precisely located on the geological map of Öland (Figs. 3 and 4).

ATTITUDE CHANGES OF PALEOZOIC LAYERS FROM THE GOTSKA SANDÖN AREA TO ÖLAND

Contouring of the Cambrian-Ordovician boundary along the Swedish east coast is due to the boreholes being best controlled around the islands of Gotland and Öland. On Gotland, where the number of boreholes is the greatest, and thus the control over the structure contours is the best, a discernible difference appears in the attitude of the Paleozoic layers between the northern and southern parts. Thus, the tilt azimuth and dip of the bedrock layers that are 145-150 $/ 9^{\prime}$ around northern Gotland, change to $130-135^{\circ} / 11.4^{\prime}$ and $120-125^{\circ} / 13.8^{\prime}$ in the middle and the southwestern part of the island, respectively. On Öland, where the altitude of the Cambrian-Ordovician boundary can be fixed in numerous outcrops and boreholes, the corresponding values are approximately $100-110 \% 11.4$.

Offshore, contouring of the Cambrian-Ordovician boundary can be controlled by the surrounding mainland data only between northernmost Öland and southernmost Gotland (Fig. 4). Thus, to contour the Cambrian-Ordovician boundary northwest/west of Gotland and north/north-east of Öland, auxiliary data points were fixed for calculating the $\mathrm{O}_{1}$ reflector altitude at points where the seismic profiles crossed the submarine Baltic Klint (Fig. 4). According to the compiled map, the tilt azimuth and inclination of the Paleozoic layers north-west of Gotland are $140-145^{\circ} / 10-11^{\prime}$. Further south, i.e. west/south-west of Visby, the tilt azimuth and inclination angle of the Paleozoic layers gradually converge to values typical for the Öland area $\left(100-110^{\circ} / 11.4^{\prime}\right)$. However, it seems that south of Visby the tilt of the bedrock layers increases slightly from the mainland towards Gotland. This is particularly evident between Öland and Gotland, as the angle of the southeasterly tilting bedrock layers around southern Gotland is 20 '.

\section{DISCUSSION} LINEAR ZONES OF DISTURBANCE: KEY TECTONIC DEFORMATION
CONTROLLING THE BALTIC HOMOCLINE STRUCTURE

The structure of the $\mathrm{BH}$, though contoured and studied in detail in NE Estonia, misses a generalizing analysis, and no attempts have been made to follow its transition from the central Baltic Sea area to the Swedish islands of Gotland and Öland. Besides a new structural map along the Swedish east coast, there are two further aspects that were taken into consideration to promote discussion of the structure of the $\mathrm{BH}$. As the structure of the platform cover depends largely on the tectonic development/structure of the underlying, directly inaccessible crystalline rocks, more attention was paid to: (1) areas with analogous tectonic/structural setting where the cratonic basement and platform cover relations in the continent interiors have been better explored and experienced; (2) the neighbouring Baltic Shield, where the rocks of the same Paleoproterozoic Svecofennian Domain are exposed and have been directly surveyed. They both provide useful information that can be directly used or widened to our study area. This concerns particularly the LZD inducing blind crustal faults, i.e. the main tectonic structures controlling the structure of the $\mathrm{BH}$.

\section{LZD AS MONOCLINE FORCED-FOLDS WITH COMPLEX HISTORY} OF THE BASEMENT FAULT

In discussions about the tectonics of the Baltic region (e.g., Suveizdis, 1979; Puura and Vaher, 1997; Šliaupa and Hoth, 2011), the cratonic basement and platform veneer associated LZD (Figs. 2 and 5) have been mostly treated as compressional basement faults of the Caledonian Orogeny. Similar stress orientation and timing estimations are based on their dominating northeasterly trend and dislocated Early Paleozoic rocks in NE Estonia. This is in spite of the fact that several LZD point towards synsedimentary movements from much earlier stages than the prime of the Caledonian Orogeny at the Silurian-Devonian transition (Puura et al., 1996; Puura and Vaher, 1997; Tuuling and Flodén, 2001). Thus, thickness/lithological analysis of the platform cover indicate clearly that many of these blind basement faults were active prior to the Caledonian Orogeny.

In fact, there are no direct data to determine explicitly either the style or the kinematic types of these blind basement faults (Fig. 5) or to date their initial creation. Thus, based purely on the orientation and age of the disturbed sedimentary rocks, any kind of suggestions as to when and in which stress-field orientation these basement faults were created, would be highly speculative (Hobbs et al., 1976).

Morphologically similar asymmetrical monoclinal folds in the platform cover above the vertical/steeply dipping basement 
faults (Fig. 5) are widespread in the interior platform of North America. There have been many studies proving that similar structures can have long and complex geological histories with versatile tectonic regimes and stress-field conditions (e.g., Stearns, 1978; Schmidt et al., 1993; Marshak and Paulsen, 1997; Johanson and Johanson, 2002; Pinet, 2016). Caused by the vertical movements of basement blocks, monoclinal folds (also called as drape or forced folds) can develop in both compressional and extensional regimes, i.e. they can be equally associated with normal or reverse faults (Stearns, 1978; Pine, 2016). Many faults have been intermittently active, revealing thus periods when high stresses with various orientations, induced along the craton margin, were transmitted into the continental interior (Marshak and Paulsen, 1997; van der Pluijm et al., 1997; Pinet, 2016).

\section{SHEAR ZONES AND FAULT ARRAYS IN THE CRYSTALLINE BASEMENT OF SOUTHERN FINLAND}

From NW Russia to the Swedish east coast, the cratonic basement along the Baltic Shield-East European Platform transect belongs largely to the Paleoproterozoic (1.93-1.8 Ga) Svecofennian Domain (Kirs et al., 2009), which was amalgamated at $\sim 1.8-1.7 \mathrm{Ga}$ into a larger, coherent and rigid mass of continental crust forming the East European Craton (Bogdanova et al., 2008). Crystalline rocks exposed in Finland and Sweden (Väisänen and Skyttä, 2007; Torvela et al., 2008 Mertanen et al., 2008; Högdhal et al., 2009), as with the basement studies in Estonia (Soesoo et al., 2004; Fig. 6), have revealed many different plate tectonic assemblages of the Svecofennian Orogeny, i.e. the crustal units that are normally separated by distinctive shear zones. Another significant time interval associated with the formation of the cratonic basement in this region coincides with postorogenic magmatism at -1.67-1.54 Ga, when large rapakivi intrusions (e.g., Vyborg, Åland, Riga) were formed (Kirs et al., 2009; Fig. 6).

Extensive studies on the shear zones and faults in Southern Finland (Elminen et al., 2008; Mertanen et al., 2008; Wenneström et al., 2008) have revealed their very complex setting, where shear zones/faults with various orientations, styles, and thus different deformation mechanisms and stress fields cross-cut each other. Based on fault types and trends, Elminen et al. (2008) distinguished seven groups of faults formed at different stages of the Svecofennian Orogeny, rapakivi magmatism and during the later epochs of cooling and exhumation of the basement. All reveal distinct features of later reactivation; some may have been active even in Mesozoic time (Smethrust et al., 1998; Larsson et al., 1999; Murell, 2003; Preeden et al., 2008, 2009).

\section{CRYSTALLINE BASEMENT STRUCTURE VERSUS LINEAR ZONES OF DISTURBANCE ACROSS THE BALTIC HOMOCLINE}

As described before, based on the trend and style, various groups of LZD appear in different areas of the BH (Figs. 2 and 3). The style of an LZD, treated in this paper as the structurally lower/higher side on the contour maps, reveals only the inclination trend of its steeper monocline limb in the platform cover. Although it also shows which fault block occurs higher/lower in the basement surface, it contains no information as to whether there is a normal or reverse fault (Fig. 5), i.e. whether it was formed in a compressional or tensional stress field. The possible strike-slip component, which is rarely seen in the platform cover at this kind of structures (Marshak et al., 2003), has been so far entirely neglected at the LZD. In this

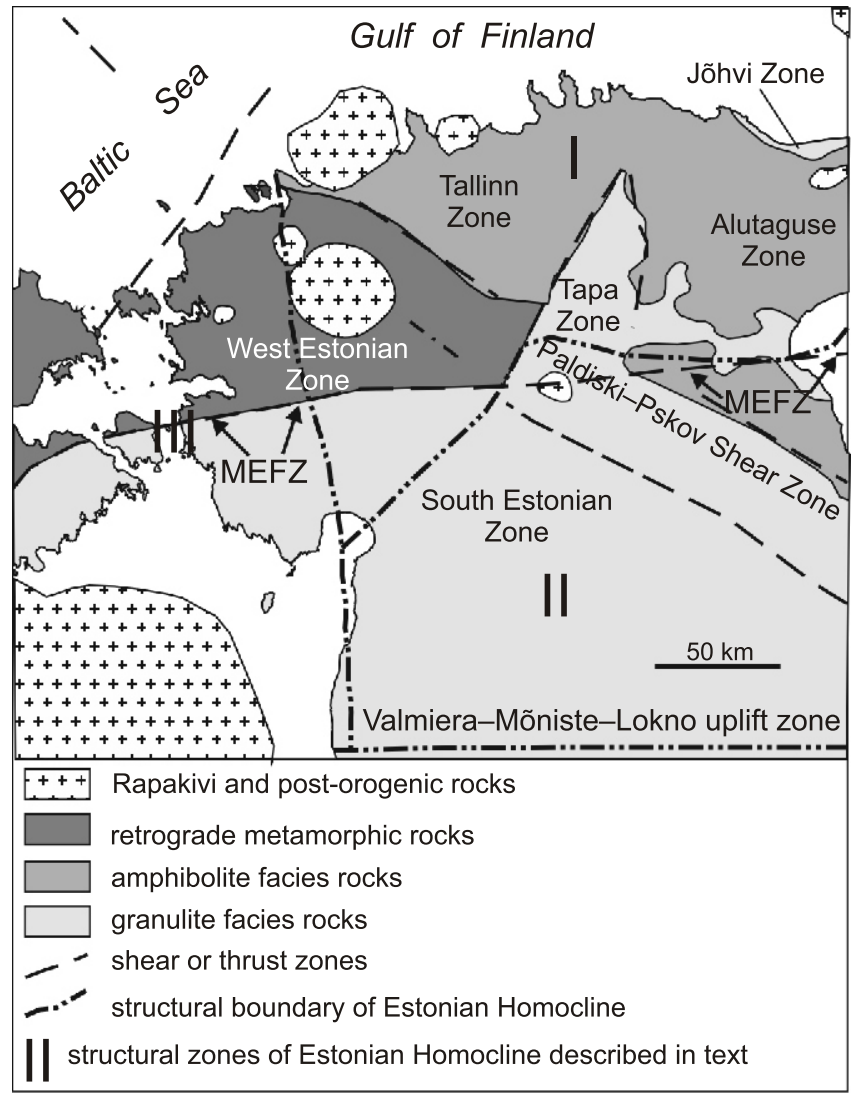

Fig. 6. The main structural units of the Estonian Homocline plotted against the major plate tectonic assemblages of the Svecofennian Orogeny in the crystalline basement of Estonia (after Kirs et al., 2009, modified)

\section{MEFZ - Middle Estonian Fault Zone}

sense, the LZD or groups of LZD that express features of a regional structural hinge-line must be more carefully analysed.

In Southern Finland, primary faulting and later reactivation processes are controlled by larger Svecofennian crustal units and extensive, well-defined shear zones that divide them (Mertanen et al., 2008). In this respect, the LZD in Estonia (particularly in the eastern part) follow to a certain extent also the main Svecofennian crustal units (Fig. 6). Thus, the set of the NE-trending LZD with structurally lowered NW sides occurs largely within the Alutaguse and Tallinn zones. The NE Estonia-Pärnu zone with regularly changing orientation and style of the LZD conforms around the Alutaguse crustal unit, and is to some extent controlled by the Middle Estonian Fault Zone (Fig. 6). However, its curved shape and the eastwesterly changing trend and style of the LZD with a wide elevated Vörtsjärve block in its central part (Fig. 2) seem to be largely controlled by the heavily uplifted section along the Liepaja-Riga-Pskov fault zone (Figs. 2 and 6). This uplifted section, also referred to as the Valmiera-Mőniste-Lokno Uplift, where the amplitude exceeds $700 \mathrm{~m}$ along deep basement faults, was formed largely during the Caledonian Orogeny in latest Silurian and earliest Devonian time (Puura and Vaher, 1997).

There are no clear basement units that controlled the distribution of the LZD in the West Estonian part. Here, the LZD with a sub-meridional or even a slight northwesterly trend and mostly with structurally uplifted western/southwestern sides cross-cut the Middle Estonian Fault Zone, and also probably some larger rapakivi intrusion(s) (Figs. 2 and 6). 
As the crystalline basement map for the offshore area is constructed based on geophysical data, no similar level comparison is possible beneath the central Baltic Sea. However, the structural hinge-line midway in the central Baltic Sea, which controls the attitude of the bedrock layers and the frequency and distribution of the submarine LZD (Fig. 3), may have a deep crustal origin. An ancient failed rift structure has been suggested by Ostrovsky (1995) beneath the central Baltic Sea, based on deep-seismic data. As the LZD have largely western sides structurally elevated west of this hinge-line, this tectonically active zone marks also the area where the crystalline basement surface starts to rise steadily towards Sweden. However, closer to the Swedish east coast, the tectonic setting, and thus the fault frequency and trends, are more likely to be influenced by the so-called Bothnian-Baltic mobile zone (Puura and Flodén, 1997; Tuuling and Flodén, 2000b, 2016).

\section{FAULT ZONES IN SOUTHERN FINLAND VERSUS LZD}

Three trends of basement faults dominant in Southern Finland, namely NE-SW, WNW-ESE-NNW-SSE and N-S (Elminen et al., 2008), are fitting well with the most frequent LZD orientations of the $\mathrm{BH}$.

Basement faults and LZD with the NE-SW trend. The NE-SW-oriented steep reverse faults of the early Svecofennian Orogeny with east/south-east-oriented kinematics constitute one of the most striking fault groups in Southern Finland. These faults were reactivated; new ones with similar trends formed during the late Svecofennian Orogeny. Palaeomagnetic studies prove that further reactivation of these faults occurred ca. $1580 \mathrm{Ma}, 440 \mathrm{Ma}, 415 \mathrm{Ma}$ and 300-250 Ma (Mertanen et al., 2008; Preeden et al., 2009). All ages coincide with well-known tectonic activation stages in this region, representing epochs of rapakivi magmatism, the Caledonian Orogeny and the Late Permian rifting/magmatism, respectively.

These basement faults fit well with the NE-trending LZD with structurally lowered NW sides, which spread widely in the North Estonian segment. Even the kinematics from the east/south-east suggests that these LZD in NE Estonia would sit on top of the reverse faults with uplifted SE sides. Synsedimentary signs reveal that some of these LZD were active in pulses during late Vendian-earliest Cambrian times (Puura and Vaher, 1997). However, their main deformation phase with the formation of platform monoclinal folds probably took place at the Silurian/Devonian transition. The bedrock remagnetisation data shows that these LZD were furthermore reactivated in Permian times (Mertanen et al., 2008; Preeden et al., 2008).

Basement faults and LZD with the WNW-ESENNW-SSE and N-S orientation. An array of WNW-ESE and NNW-SSE-oriented faults in Southern Finland represents straight normal extensional or sinistral strike slip faults that dip at angles of $75-90^{\circ}$, both to the NE and SW. These are the most abundant rapakivi granites cross-cutting faults, i.e. they are related either to the rapakivi or to some later tectonic epochs. The $\mathrm{N}-\mathrm{S}$ faults are post-rapakivi sinistral strike-slip faults that cross-cut the previous trends. The stress-field of these very long vertical to high-angle $\mathrm{N}$-S-striking faults suggests that this strike-slip movement would have also caused horizontal movements in the WNW-ESE- and NNW-SSE-trending normal faults.

The last two fault trends fit with the prevailing LZD orientations in the western half of the $\mathrm{BH}$ (Figs. 2 and 3). The group with slightly NW-trending LZD is confined within a narrow wedge that includes the Vihterpalu LZD and a $50-75 \mathrm{~km}$ wide area south-west of it (Fig. 2). The submeridional trend dominates on the West Estonian islands and beneath the central Baltic Sea. Like the faults in Southern Finland, the LZD with similar trends in West Estonia are also straight, distinctive and long structures that most probably cross-cut the Middle Estonian Fault Zone (Fig. 6). Coinciding with a structural hinge-line, the Vihterpalu LZD probably also traverses the large Märjamaa rapakivi intrusion (Figs. 2 and 6). The LZD with the NNW-SSE trends may also have either the NW or SE sides structurally lowered.

It is difficult to estimate either the kinematics or the type of the basement faults that created the LZD with similar trends. Even so, the occurrence of numerous graben-/horst-like structures beneath the eastern part of the central Baltic Sea hints rather to the normal faults of an extensional regime. No strike-slip component, typical for similarly trending basement faults in Southern Finland, has been traced in the platform cover of Estonia. However, there are some indications suggesting that besides dip-slip, fault that underlies the Vihterpalu LZD may also have an oblique strike-slip component.

First, the strike of the bedrock layers on both sides of the Vihterpalu LZD deviates distinctively from that in the surrounding areas (Fig. 2). Thus, the narrow wedge with the NW-trending faults of various styles, south-west of the Vihterpalu LZD, may point towards some strike-slip "jostling" of the basement blocks. Secondly, this structural hinge-line also slightly modifies the course of the Baltic Klint. The latter, across the $\mathrm{BH}$ extending escarpment, which has an approximate $\mathrm{W}-\mathrm{E}$ course in northern Estonia, attains a slight southwesterly trend in northwestern Estonia (Tuuling and Flodén, 2016).

No clear reactivation signs have been discovered for this group of basement faults in Southern Finland. However, according to synsedimentary indications in the platform cover, the Vihterpalu LZD was active in Early Cambrian times (Puura and Suuroja, 1984; Tuuling and Flodén 2001: fig. 9). Thus, monoclinal platform folds with similar orientations were largely formed during the Caledonian Orogeny at the Silurian/Devonian transition.

\section{TECTONIC SETTING VERSUS BEDROCK STRUCTURE ALONG THE SWEDISH EAST COAST}

Bothnian-Baltic mobile zone. In the regional setting, the area along the Swedish east coast has been a high tectonic activity zone since Mesoproterozoic times, being characterized by an increased number and amplitude of dislocations that have been repeatedly reactivated. Thus, the Swedish coastline is in places, particularly in the Gulf of Bothnia, controlled by ancient basement faults and is bordered by series of down-faulted Precambrian rift-type structures (viz. Bothnian Bay, Bothnian Sea, Åland Sea, Landsort Trench: Flodén, 1980; Winterhalter et al., 1981; Wännas, 1989; Söderberg, 1993). During Early Paleozoic times, this zone also controlled the distribution/configuration of the sedimentary basins that developed in this region (Flodén, 1980; Basset et al., 1989; Hagenfeldt, 1994; Puura and Flodén, 1997; Tuuling and Flodén, 2000b). Dividing the tectonically opposite and oblique movement areas, this intracratonic deep crustal Baltic-Bothnian mobile zone (Puura and Flodén, 1997) also terminates the western extension of the southerly sloping BH (Tuuling and Flodén, 2016).

Landsort-Fårö area: a highly active segment of the Bothnian-Baltic mobile zone and Baltic Homocline contact. Although the $\mathrm{BH}$ reveals increased tectonic activity with minor 
modifications in the structural setting already NE of Gotland, a significant change in the attitude of the bedrock layers is brought about by a group of deep basement faults/fault systems around northern Gotland (Flodén, 1980: fig. 18; Fig. 4). This group of radially spaced faults with a northwestwards increasing trend forms the heavily deformed fan-shaped Landsort-Fårö sector (Flodén, 1980) that widens from Gotland towards the Swedish east coast in the north-west (Fig. 4). Thus, if a few easternmost fault lines just west of Gotska Sandön still have a submeridional trend that is typical for the LZD in the central Baltic Sea area, then the northwesterly strike of the faults becomes dominant towards Sweden and prevails further south along its east coast (Fig. 4). Exceptionally, the heavily deformed Landsort-Fårö sector is limited from the north-west by a northerly- to northeasterly-trending curvilinear fault system that bounds the narrow Landsort Trench (see All et al., 2006: fig. 3; Fig. 4), with the deepest point $(-459 \mathrm{~m})$ below the Baltic Sea.

The Landsort-Fårö sector manifests a very complex architecture with significant, along the high-angle to the vertical faults and fault systems down-faulted and occasionally tilted basement blocks. The amplitudes between different faults, and even along the same faults, can vary considerably. Due to a stepwise subsidence and tilting, occurring occasionally along closely spaced parallel faults (Flodén, 1980: figs. 14a, b, 16), the Landsort-Fårö sector resembles a half-graben. Seismic data reveal two down-faulted Mesoproterozoic sedimentary basins within the Landsort-Fårö sector (Flodén, 1980). Based on geophysical modelling (All et al., 2006) these graben-like structures, filled with Jotnian sandstones $(\sim 1.4-1.3 \mathrm{Ga})$, have supposedly inherited their position from deep-seated rapakivi intrusions $1.57 \mathrm{Ga}$.

The Landsort-Fårö sector has a complex and long-lasting history. Since the first faulting epoch, suggested during the formation of a rapakivi intrusion, several stages of Proterozoic-Phanerozoic tectonic activities alternating with extensive periods of erosions have been distinguished (All et al., 2006). The greatest fault offset, $\sim 900 \mathrm{~m}$, measured in the Jotnian sandstones, belongs to the post Jotnian formation of the graben-like sedimentary basins. The sections of the Landsort-Fårö faults that are buried beneath the Cambro-Ordovician rocks reveal no direct signs of Early Paleozoic activity (Flodén, 1980). However, significant thickness variations of the Cambrian sequence around northern Gotland and Gotska Sandön (Thorslund, 1958; Tuuling et al., 1997; Nielsen and Shovsbo, 2011), obviously related to basement-block movements, hints that this region was also tectonically active in Cambrian times. The increased number of LZD with structurally higher western sides just NE of Gotland (Figs. 3 and 4) suggests that this area was tectonically activated also during the prime of the Caledonian Orogeny.

The latest tectonic reactivation of the Landsort-Fårö sector has been discussed in connection with the origin of the Landsort Trench, which is running along the $\mathrm{N}-\mathrm{S}$ and NE-SW directional fault sets (Fig. 4). Within this trench, the crystalline basement surface, being covered only with a 190-200 m thick set of unspecified Pleistocene glacial and Baltic Sea sediments drops nearly $500 \mathrm{~m}$ in respect to the surrounding areas (Flodén and Brännström, 1965; Flodén 1980: figs. 19, 20). However, both fault sets extend outside the trench, where they can be followed as about 15-20 km long fracture valleys in the crystalline basement. Thus, Flodén (1980) suggested that final fault activation with rock crushing, which facilitated final shaping of the Landsort Trench by selective glacial erosion in the Pleistocene, occurred during the Cenozoic uplift of Scandinavia. In a later interpretation (All et al., 2006), the last Landsort-Fårö activation epoch was thought to have occurred in Paleozoic times, and thus a deep trench-like incision was entirely shaped by Pleistocene sub-glacial erosion. However, as will be discussed below, the recent structural rearrangements along the Swedish east coast suggest that the Landsort-Fårö area was tectonically active obviously also during the Late Cenozoic. Thus, before the glacial erosion, there occurred also some down-faulting/crushing of the rocks in the Cenozoic, which facilitated removal of the rocks from the Landsort Trench.

In comparison with a steady westerly/southwesterly rise of the crystalline basement surface in the western half of the central Baltic Sea, the down-faulted Landsort-Fårö sector strikes as some sort of structural turning/bending area between the Swedish east coast and the Baltic Sea. Thus, the numerous basement faults with LZD north-east of Gotland (Figs. 3 and 4) are obviously closely related to the Precambrian establishment of the Landsort-Fårö sector and have been directly influenced by its complex geological history. They were possibly also reactivated concurrently with the latest activation of the Landsort-Fårö sector in connection with the basement uplift and structural rearrangements that occurred along the Swedish east coast in Cenozoic times.

In general, the complex architecture with down-faulted and tilted basement blocks, frequently in a stepwise manner, suggests extensional/strike-slip tectonics. Following the history of formation and the present structural setting of the platform cover, the Landsort-Fårö sector has repeatedly acted as a zone of crustal weakness. Thus, the tectonic activation of this sector affected the development of the Baltic Ordovician-Silurian Basin, and played an important role in shaping the Cenozoic terraced morphostructure along the Baltic Shield-East European Platform transect (Tuuling and Flodén, 2016).

\section{FACIES ZONATION IN THE BALTIC ORDOVICIAN-SILURIAN BASIN} VERSUS THE PRESENT STRUCTURAL SETTING

Following the facies zonation, the nearshore area of the Baltic Ordovician Basin extends largely across the southern slope of the Baltic Shield (Männil, 1966; Grahn and Nölvak, 2010: fig. 1), i.e. it coincides with the BH (Fig. 7). The deep-basinal area remains further south/south-west towards the central Baltic Sea and the Swedish east coast. A similar facies distribution predicts a structural setting where the southerly deepening layers on the shield slope and the southwesterly tilted units beneath the central Baltic Sea, as well as along the Swedish east coast would have W-E and NW strike, respectively.

In this sense, the structure contours of the $\mathrm{BH}$ (Figs. 2 and 3 ) follow more or less the ancient structural setting. However, to the south, and particularly towards the Swedish coast in the south-west, the present bedrock attitude (Fig. 4) deviates increasingly from that of the Baltic Ordovician Basin (Fig. 7). Thus, the present northeasterly strike and southeasterly lowering structure contours of the Ordovician layers around the Gotland-Öland area prove that the bedrock sequence along the Swedish east coast had been uplifted and was tilted towards the south-east by later tectonic activity.

Since the end of Ordovician times, the progressing Caledonian Orogeny changed the regional structural setting, as a large depression (the Baltic Syneclise) started to evolve in the centre of the Palaeobaltic Basin (Fig. 7). Thus, adjusting along the margins of this new depocentre, from Estonia across Gotland extending Silurian facies attained a NE-SW trend (see Kaljo et al., 1991: fig. 4; Loydell et al., 1998: fig. 3) that is more similar to the present structural situation close to the Swedish east coast (Figs. 4 and 7). 


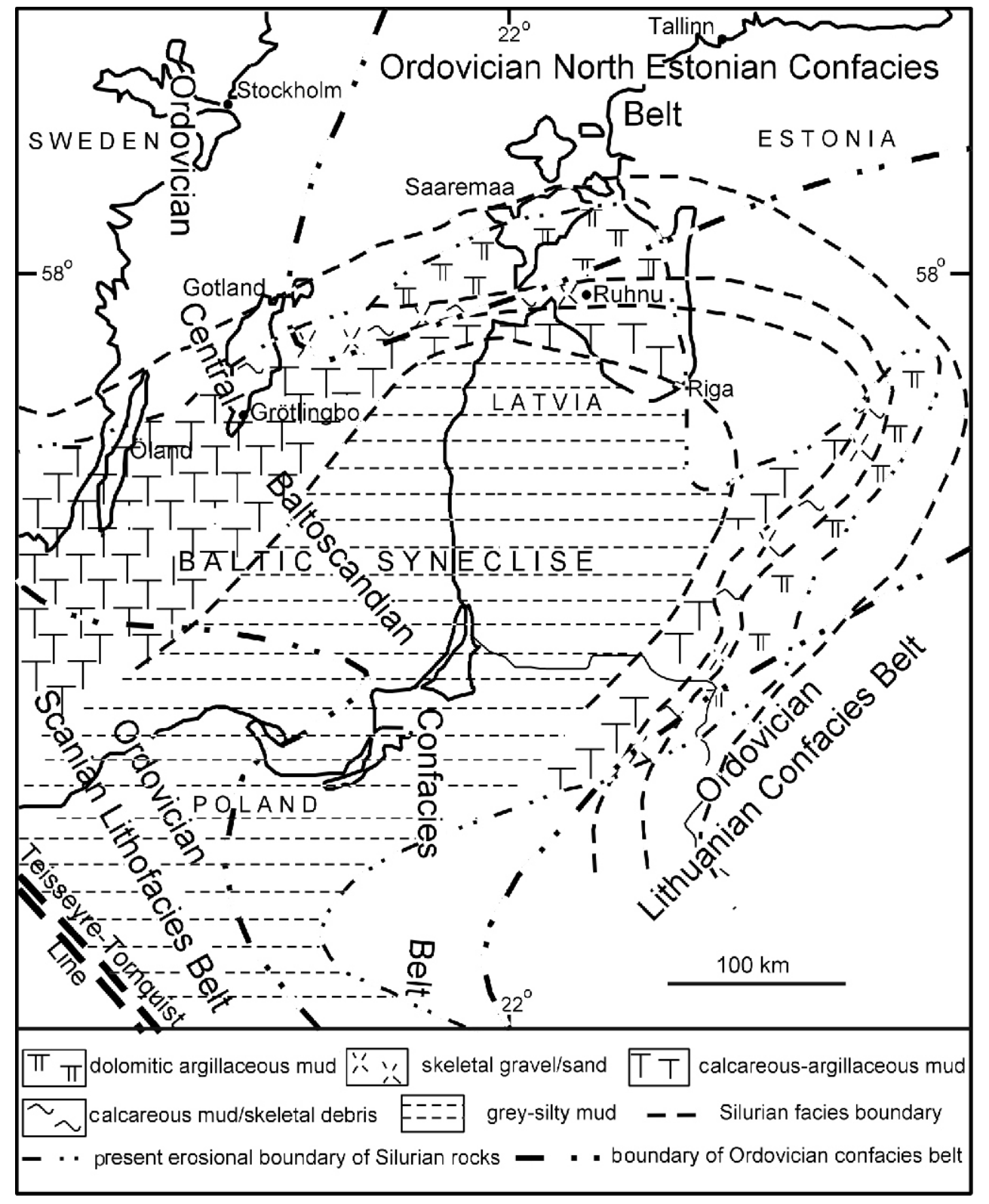

Fig. 7. Generalized map showing the facies zonation/distribution changes induced by the Caledonian Orogeny in the Palaeobaltic Ordovician-Silurian basin

Facies distribution in the Ordovician sketched after Grahn and Nölvak (2010); in the Silurian (Late Wenlock - Jaagarahu-Rootsiküla time) modified after Kaljo et al. (1991)

As the Gotland-Öland area occurs around the northwestern flank of this down-warped depression, the basinal trends there probably suffered significant changes already in Silurian times. Indeed, signs of submarine erosion and channelling in the latest Ordovician-earliest Silurian sequence offshore Gotland (Tuuling and Flodén, 2007, 2009b), as well as extensive hiatuses at the O/S boundary and in the lowermost Silurian sequence (Martinsson, 1968; Grahn, 1995) below Gotland, point unambiguously towards an unstable slope environment and increasing tectonic activity near the Swedish east coast. However, the depth-related sharp facies/faunal differences between eastern and western Gotland suggest that the Silurian basin around Gotland was still deepening towards the west/south-west (Jeppson et al., 1994, 2006). Thus, the structural rearrangement with the uplift and tilting of the bedrock lay- ers along the Swedish east coast continued after Early Paleozoic time.

Possible magnitude and timing of structural rearrangements around the Gotland-Öland area. Because the youngest bedrock around the Gotland-Öland area is of Silurian age, there are no direct data for analysing post-Caledonian structural rearrangements along the Swedish east coast, either for timing these events or for estimating their magnitude. The differential tectonic movements, varying thicknesses of the accumulated sediments, later erosion, and still ongoing glacioisostatic rebound, have all changed the relationships between the positions of the geological boundaries that can be contoured for structural analysis. Thus, their present altitude differences with the tilting trends (Figs. 2-4) are only the sum of these long-term differential movements/events. It is impossible to decipher, i.e. 
to estimate when exactly these structural setting rearranging tectonic events occurred and what was their possible magnitude in a particular area.

Role of the Caledonian Orogeny. As described above, the Gotland-Öland area, which in the southwestward-sinking Ordovician Basin occurred in a deeper facies zone than most of the present central Baltic Sea, attained with respect to the latter area structurally higher position already during the formation of the Baltic Syneclise (Fig. 7). However, as the evolving syneclise was regularly filled and finally levelled by Silurian sediments, it is likely that the structural differences induced by the depression around the Swedish east coast gradually waned towards the end of Silurian period. Thus, the magnitude of the structura changes induced by the Caledonian Orogeny along the Swedish east coast is best reflected in the pre-Silurian layers, i.e. also on the Cambrian-Ordovician boundary based structure contour maps represented in this paper (Figs. 2-4).

The Ordovician facies/units exposed in northern Öland are $\sim 440 \mathrm{~m}$ lower in the Grötlingbo core in southern Gotland (Figs. 1 and 7). Across the Baltic Sea, the same facies/units occur first to $\sim 670 \mathrm{~m}$ b.s.l. in the Gulf of Riga (Ruhnu core in Figs. 1 and 7 ) and then rise towards the southeastern corner of Estonia, reaching 280-290 m b.s.I. in the Tartu core (Figs. 1 and 2). Hence, the evolution of the Baltic Syneclise, which induced a relative uplift of the Gotland-Öland area, also down-warped a weak syncline-like structure into the Ordovician sequence between Sweden and Estonia.

Besides being tilted to the south-east, the Silurian rocks along the Swedish east coast are also clearly uplifted, as the facies exposed on Gotland are buried below Saaremaa and occur at a much lower elevation beneath the central Baltic Sea (Tuuling and Flodén, 2009b, 2011, 2013). Because the Silurian units across the Baltic Sea are incomparable directly, it is difficult to juxtapose altitude differences of the coeval Silurian layers between Saaremaa and Gotland. However, the coeval Silurian reefs, which once developed along a shallow shelf in the same depth zone (Nestor, 1995), occur $\sim 80-90 \mathrm{~m}$ higher up in northern Gotland and 170-180 m in central Gotland than their counterparts beneath the central Baltic Sea (Tuuling and Flodén, 2001, 2013). Thus, the uplift magnitude of the Silurian layers increases towards southern Gotland.

Late Paleozoic tectonic activity. There are no direct data as to whether and how the Permo-Carboniferous tectonic reactivation epoch changed the structural setting around the Gotland-Öland area. However, signs of intense tectonic movements in the surrounding areas (Sopher et al., 2016 and references herein) do not exclude such possibility. Intense faulting occurred along the Bornholm-Darłowo fault zone in the nearby southwestern Baltic Sea (Šliaupa and Hoth, 2011), and further down-faulting of the Precambrian fault-related Jotnian basin took place along the Bothnian-Baltic mobile belt in the Gulf of Bothnia (Puura et al., 1996).

POST-PALEOZOIC TECTONIC ACTIVITY AND RELIEF ANALYSIS OF SOUTHERN SWEDEN

Two post-Paleozoic tectonic activation epochs are distinguished in this region, which, to a lesser or greater extent, influenced and obviously also rearranged the structural setting in the Gotland-Öland area. The first is expressed by the tectonic activity increasing towards the end of Mesozoic times around southern Sweden, which culminated in the Late Jurassic reactivation of the Bornholm-Darłowo fault zone (Krzywiec et al., 2003; Šliaupa and Hot, 2011). The second epoch induced large-scale basement movements around the North Atlantic and Scandinavia in two stages of the Cenozoic Era. Besides forming largely the present-day morphostructure of the Baltic Shield, the early and late Cenozoic Scandinavian uplift stages (Japsen and Chalmers, 2000; Anell et al., 2009) structurally rearranged its southern/southeastern margins along the contact with the East European Platform.

Detailed relief analysis in southern Sweden reveals a complex set of peneplains with various ages, the formation of which is explained by a long-term Mesozoic-Cenozoic tectonic/denudation history (Lidmar-Bergström, 1999; Lidmar-Bergström et al., 2013; Green et al., 2013). Thus, since Mesozoic times, this region has been characterized by periods of differential basement uplift/tilting and denudation that alternated with intervals of subsidence, inundation and burials. At a dome-like, tectonically dynamic topographic high called the South Swedish Dome located just west of the islands of Öland and Gotland (Fig. 4), three uplift/denudation stages are distinguished: Mesozoic (Jurassic-Cretaceous), early Cenozoic, and late Cenozoic. The late Cenozoic (Neogene) uplift, inducing $\sim 800-1200 \mathrm{~m}$ rise of the Southern Scandes, also elevated the South Swedish Dome by some $150 \mathrm{~m}$ (Lidmar-Bergström and Näslund, 2002; Lidmar-Bergström et al., 2013).

\section{CENOZOIC UPLIFT OF SCANDINAVIA VERSUS CUESTA-TYPE MORPHOSTRUCTURE AT THE BALTIC SHIELD-EAST EUROPEAN PLATFORM TRANSECT}

The uplift of Scandinavia in Cenozoic times intensified, clearly showing tectonic activity along the Baltic Shield-East European Platform transect, and rearranged the structural setting of the nearby platform areas. The uplift of the Southern Swedish Dome and down-faulting of the Landsort-Fårö sector (with possible basement uplift north-east of this sector) proves that the latest Cenozoic structural rearrangements around the Gotska Sandön and Öland areas were significant. In general, the Cenozoic uplift of the Baltic Shield with differential movements along the Bothnian-Baltic mobile zone boosted erosion and created a structural setting needed for the development of a cuesta-type terraced morphostructure at the Baltic Shield-East European Platform transect. Thus, based on the attitude of the bedrock layers, this terraced relief can be divided into two sections (Tuuling and Flodén, 2016; Fig. 1): (1) within the $\mathrm{BH}$, on the southern slope of the Baltic Shield; and (2) along the Swedish east coast, south of Gotska Sandön.

Cuesta relief on the southern slope of the Baltic Shield. On the uplifted, gently southerly/southwesterly dipping slope of the Baltic Shield, a W-E-running set of rivers was established along the contact of the hard erosion-resistant and soft, easily erodible rock layers in Cenozoic times (Tuuling and Flodén, 2016). These rivers were the tributaries of the larger southward-flowing Eridanos River (Fig. 1), which, based on an extensive set of deltaic sediments of Scandinavian origin between northern Poland and the North Sea, flowed somewhere near the Swedish east coast in Cenozoic (Neogene) times (Overeem et al., 2001). Due to a homocline setting, the westward-flowing streams shaped an extensive cuesta-type bedrock relief on the southern slope of the Baltic Shield. Emerging faintly along the Gulf of Finland and around the north Estonian coast, this ENE-SSW-trending cuesta setting is particularly well expressed beneath the central Baltic Sea (see Tuuling and Flodén 2016: fig. 6; Figs. 3 and 8).

Cuesta relief along the Swedish east coast. The bedrock layers along the Swedish east coast had a structurally higher 


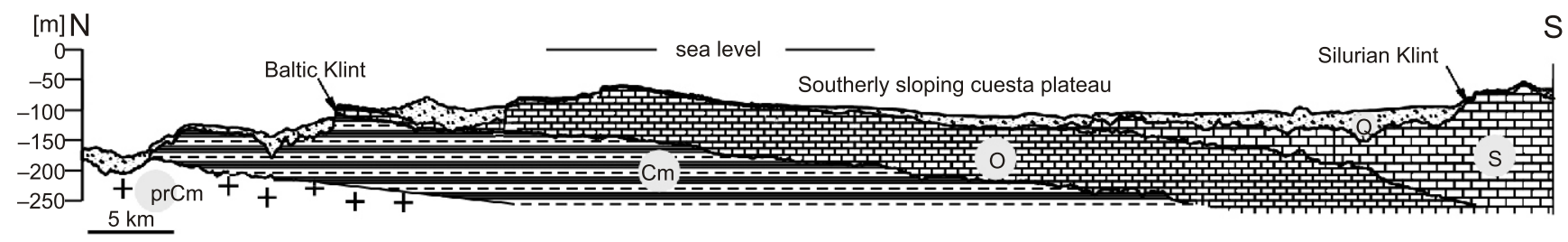

Fig. 8. Geological cross-section showing the cuesta-type relief with a large asymmetrical cuesta valley within the Baltic Homocline on the southern slope of the Baltic Shield

(modified after Tuuling and Flodén, 2016)

For location see Figure 3

position with a gentle southwesterly tilt that was already evident in pre-Cenozoic times. However, differential basement movement around the Landsort-Fårö and Öland areas in Cenozoic times changed this setting, as the rising South Swedish Dome uplifted and tilted the bedrock cover in the nearby platform area. Similar to the southern slope of the Baltic Shield, a terraced cuesta relief started to develop along this section of elevated and tilted shield-platform transect (Figs. 1 and 9). Because the relief fell from the Öland area towards Gotska Sandön, the rivers that evolved here along the hard erosion-resistant and soft easily erodible rock layers ran most probably toward the $\mathrm{NE}$, and were thus the western tributaries of the southward-flowing Eridanos River (Fig. 1).

A possible valley, lowering from the elevation of $50 \mathrm{~m}$ b.s.l. south of Öland up to $120 \mathrm{~m}$ b.s.l. west northwest of Gotland, was pointed out already by Martinsson (1958). He had a strong suspicion that there was also a larger $\mathrm{N}-\mathrm{S}$-trending preglacial valley passing through eastern Gotland. However, as there was no proof for this valley, and the bedrock altitudes east of Gotland and from the southern Baltic Sea did not support this idea, he left the problem about possible Cenozoic river sets and their directions around the Gotland-Öland area open.

Thus, the terraced relief along the Swedish east coast was evidently shaped by a northeasterly flowing tributary of the Eridanos River, which joined this river somewhere around northern Gotland (Fig. 1). The possible valley of Eridanos, which was most probably accommodated along the Bothnian Baltic mobile zone, was obviously destroyed by Pleistocene glaciers, as one of its main lobes followed the Gulf of Bothnia and passed eastern Gotland. Traces of glacial erosion with heavily destroyed and smoothed preglacial terraced relief with great thicknesses of glaciofluvial sediments around northern Gotland, Fårö and Gotska Sandön are overwhelming (Flodén, 1980; Noormets and Flodén, 2002; Tuuling and Flodén, 2016). Equally convincing are the Fårö and Gotland depressions north-east and east of Gotland, which obviously were moulded into bedrock by melt water under glacial pressure.

In all, the islands of Öland and Gotland emerge on the uplifted Swedish east coast as bedrock remnants shaped mostly by large Cenozoic rivers that had opposite directions in the west and east of the islands. However, as the tilt of the bedrock layers here is roughly twice as high as that of the $\mathrm{BH}$, the terraced cuesta relief along the Swedish east coast differs clearly from that on the southern slope of the Baltic Shield (Figs. 8 and 9). Steeper and narrower terraces induce a higher depth gradient towards Gotland and the terraced area between Gotland and Swedish mainland, which, differently from the central Baltic Sea area (Tuuling and Flodén, 2016) does not have extensive asymmetrical cuesta valleys, is squeezed together (Fig. 9). However, like on the southern slope of the Baltic Shield, the cuestas-shaping rivers along the Swedish east coast reveal clearly that their bank-erosion increased downstream. Thus, the area of exposed crystalline rocks widened regularly towards Gotska Sandön from both the Öland and the northern Estonia sides. As a result, shaped by western and eastern tributaries of the Eridanos River and around northern Gotska Sandön joining two different cuesta settings create an imagination of unique, from NW Russia to the southern tip of Öland arching terraced relief.

Question of the unique Baltic Klint. The interpretation that terraces west of Gotland and Öland were shaped by a northeasterly flowing tributary of the Eridanos River requires a revaluation of the term Baltic Klint, which so far has been treated as unique, from the Lake Ladoga area in the north-east to the southern tip of the Öland extending escarpment (Tammekann, 1940; Tuuling and Flodén, 2016). Thus, this escarpment must be divided into two sections shaped by different tributaries of the Eridanos River. Its subparallel section on the southern slope of the Baltic Shield was induced by the Pra-Neva River (Puura, 1980; Fig. 1) and includes the Ingermanland, the North Estonian and the central Baltic Sea klints (Tuuling and Flodén, 2016; Figs. 1 and 3). The section,

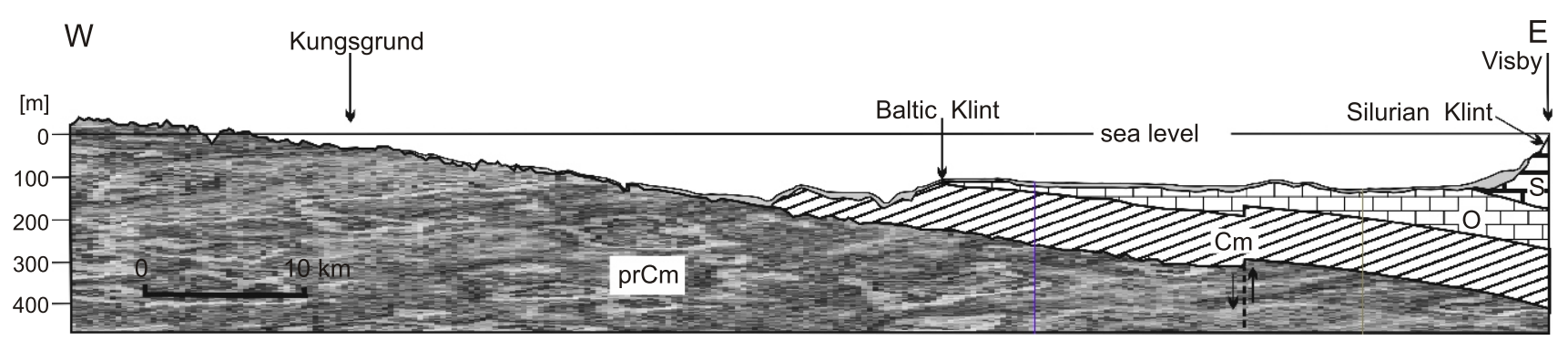

Fig. 9. Geological cross-section showing the cuesta-type relief along the Swedish east coast between the mainland and Gotland (modified after Flodén, 1980) 
shaped by a northeasterly running river along the Swedish east coast, however, embraces the submarine klint west of Gotland and the Öland Klint. Hence, another impressive cuesta scarp, the Silurian Klint between Saaremaa and Gotland (Figs. 1 and 3), is divided by the Eridanos River in the same way into the eastern (Saaremaa-Central Baltic Sea) and western (Gotland) sections.

\section{CONCLUSIONS}

The signs of accretion of new crust, rifting, and truncated tectonic trends indicate that high stresses affected repeatedly the area along the margin of the East European Craton during its interactions with other tectonic plates (Bogdanova et al., 2005, 2008; Gee and Stephenson, 2006). Besides deforming the craton margins heavily, similar stresses are often transmitted $1000 \mathrm{~s} \mathrm{~km}$ to remote continental interiors, where they can induce significant intracratonic tectonic movements (Marshak and Paulsen, 1997; van der Pluijm et al., 1997; Pinet, 2016). Intracratonic basement faulting/reactivation of older faults, besides often controlling the formation of the platform cover, also determines its general structural setting and the style of tectonic deformation. The structural setting and architecture of the platform cover designed by intracratonic tectonic activities have played a crucial role in controlling the erosional processes and shaping the cuesta-type bedrock morphostructure along the shield platform contact around the northern Baltic Sea.

Concerning the structure of the intracratonic $\mathrm{BH}$ and its transition to the Swedish east coast, the following conclusions can be made:

1. The structure of the $B H$ is controlled largely by the LZD that morphologically represent typical, monoclinal forced or drape folds in the platform cover induced by basement faulting.

2. There appears to be a distinctive spatial regularity in the trends and styles of the LZD, which is partly controlled by large basement units of the Svecofennian Orogeny (North Estonian segment), and in places by extensive hinge-line type zones with increased tectonic activity traversing the $\mathrm{BH}$ meridionally (West Estonian and central Baltic Sea area). In the northeastern Estonia-Pärnu zone, the changes in style and trends of the LZD, as well as the basement faulting, seem to be induced and controlled largely by intensive block faulting along the Liepaja-Riga-Pskov fault zone during the Caledonian Orogeny.

3. Based on the basement structure caused variability/regularity in the distribution of the LZD in Estonia and studies on the basement faults in Southern Finland, there are strong indications that the platform monoclinal folds inducing basement faults were formed during different tectonic activation epochs at various stress-field conditions. Thus, many of the LZD sit on older Precambrian basement faults, which can be dated back to the early Svecofennian Orogeny. As for the basement weakness zones, these faults have been repeatedly reactivated in various kinematic/stress conditions throughout later geological history, although their present style and magnitude with an overlying monoclinal fold is shaped largely by the Caledonian Orogeny.

4. Most of the LZD cause minor attitude variations in the bedrock layers across the $\mathrm{BH}$. The regional-scale modifications in the tilt azimuth/angle of the platform cover occur at the extensive hinge-line type of tectonic zones traversing the $\mathrm{BH}$ northsoutherly (Vihterpalu LZD, Central Baltic Sea zone). These hinge-lines also control the number, trend and style of LZD within different segments of the $\mathrm{BH}$. The western extension of the $\mathrm{BH}$ is bounded by one of the most active tectonic hinge-lines in this region, the Bothnian-Baltic mobile zone, where the attitude changes of the Early Paleozoic rocks are significant.

5. The Swedish east coast with the islands of Gotland and Öland runs along the Bothnian-Baltic mobile zone that separates Scandinavia from the Baltic Sea area. This zone reveals signs of increased tectonic activity since Mesoproterozoic times and has been reactivating in pulses until the latest Cenozoic time. The Landsort-Fårö sector, as one of the most active areas within this zone, has obviously played an important role in the formation of the present structural setting of the platform veneer, as well as the cuesta-like morphostructure around the Gotland-Öland area.

6. The first major structural rearrangement of the Early Paleozoic platform cover along the Swedish east coast was obviously induced by the Caledonian Orogeny. Thus, the formation of a large depocentre east/southeast of the Gotland-Öland area changed the basinal trends typical for the Baltic Ordovician basin, and also probably down-warped the areas further east of Gotland. As a result, the Gotland-Öland area became structurally placed at a higher position than most of the central Baltic Sea area.

7. Another crucial structural rearrangement of the Gotland-Öland area is obviously associated with the (latest) Cenozoic uplift of Scandinavia, which brought about differential tectonic movements with some uplift and tilting of the platform cover between the Landsort-Fårö sector and the South Swedish Dome.

8. Successive uplifting/tilting of the Ordovician-Silurian rocks along the Swedish east coast, as well as their possible down-warping in the central Baltic Sea area during the formation of the Baltic Syneclise, has shaped the syncline-like bedrock structure between the Swedish east coast and Estonia. A similar syncline in the Paleozoic rocks between Estonia and the Swedish islands of Gotland-Öland, though symmetrical, has already been drawn in the very first geological cross-sections across the Baltic Sea (Schmidt, 1881: fig. 8; see Tuuling and Flodén, 2009a: fig. 2). However, as the uplift and bending occurred mostly close to the Swedish coast, the formed syncline is highly asymmetrical, with a much shorter and steeper western/southwestern Swedish limb.

9. Induced by the (latest) Cenozoic uplift the structural setting of the platform veneer established the conditions for developing an extensive terraced cuesta-type morphostructure along the Baltic Shield-East European Platform transect. As the $\mathrm{BH}$ on the southern slope of the Baltic Shield and the Paleozoic strata along the Swedish east coast had different attitudes, two isolated terraced cuesta-type relief systems with different orientations began to develop. Since both systems had an outlet into the Eridanos River around the Gotska Sandön area, a false impression of a unique terraced cuesta setting with the continuous Baltic Klint, extending from NW Russia to the Swedish island of Öland, was developed. 
10. The Baltic Klint consists of two isolated sections shaped by different tributaries of the Eridanos River, and has to be divided into the eastern and western portions. The first was shaped by the westerly running Pra-Neva River and extends from NW Russia to the Gotska-Sandön area and includes the Ingermanland, North Estonian and central Baltic Sea klints. The western, northeasterly running tributary of the Eridanos River shaped the Öland Klint and the submarine Ordovician Klint west of Gotland. The islands of Gotland and Öland emerged on the structurally uplifted/tilted Swedish east coast as erosional remnants of the Paleozoic rocks, shaped by Cenozoic rivers.

11. Geologically and geomorphologically, the klints/escarpment systems along the Swedish east coast and on the southern slope of the Baltic Shield are very similar. Having the same Paleozoic succession and analogous structural setting along the shield-platform boundary, they both were formed by fluvial erosional processes of the same Cenozoic river set and later subjected to
Pleistocene glacial reworking. As such, they are uniform for many observers and researchers.

12. Geographically, they form a uniform regional semi-continuous pattern. The possible differences in age and traces of different palaeo-rivers in different segments of this belt would deserve comparative description, considering their similarities and differences, which could provoke additional studies.

13. The present northern Baltic Sea depression and its configuration (branches of the Gulf of Finland and the Gulf of Bothnia) with the large islands off the Swedish east coast (Gotland and Öland) have greatly been shaped by a preglacial river set that evolved on the slopes of the Baltic Shield in connection with the Late Cenozoic uplift of Scandinavia.

Acknowledgements. This research was supported by the Estonian government institutional grant (IUT20-34). The author is particularly indebted to the reviewer Prof. V. Puura whose valuable comments helped significantly to improve the manuscript.

\section{REFERENCES}

All, T., Flodén, T., Puura, V., 2006. A complex model of Mesoproterozoic sedimentary and igneous suits in a graben setting north of Gotland, Baltic Sea. GFF, 128: 53-63.

Anell, I., Thybo, H., Artemieva, I.M., 2009. Cenozoic uplift and subsidence in the North Atlantic region: geological evidence revisited. Tectonophysics, 474: 78-105.

Baarli, B.G., Johnson, M.E., Antoshkina, A.I., 2003. Silurian stratigraphy and paleogeography of Baltica. New York State Museum Bulletin, 493: 3-34.

Bassett, M.G., Kaljo, D., Teller, L., 1989. The Baltic region. National Museum of Wales, Cardiff. Geol. Ser., 9: 158-170.

Bogdanova, S.V., Gorbatschev, R., Garetsky, R.G., 2005. The East European Craton. In: Encyclopedia of Geology (eds. R.C. Selley, L.R. Cocks and I.R. Plimer): 34-49. Elsevier.

Bogdanova, S.V., Bingen, B., Gorbatschev, R., Kheraskova, T.N., Kozlov, V.I., Puchkov, V.N., Volozh, Yu.A., 2008. The East European Craton (Baltica) before and during the assembly of Rodinia. Precambrian Research, 160: 23-45.

Brio, H.S., Kucherenko, V.P., Kursheva, V.F., 1981. New data on the structural setting of the Paleozoic rocks in the area of the Valmiera Uplift (in Russian). In: Conditions for formation of the platform cover and tectonic structures in the Baltic countries (ed. B.L. Afanasjev): 67-71. Zinatne, Riga.

Calner, M., Jeppsson, L., Munnecke, A., 2004. The Silurian of Gotland - part I: review of the stratigraphic framework, event stratigraphy, and stable carbon and oxygen isotope development. Erlanger Geologische Abhandlungen, Sonderband, 5: 113-131.

Elminen, T., Airo, M.-L., Niemelä, R., Pajunen, M., Vaarma, M., Wasenius, P., Wennerström, M., 2008. Fault structures in the Helsinki area, southern Finland. Geological Survey of Finland, Special Paper, 47: 185-213.

Erlström, M., Pesrsson, L., Sivhead, U., Wickström, L., 2009. Beskrivning till regional berggrudskarta över Gotlands län. Sveriges Geologiska Undersökning. Lenanders Grafiska: 1-60.

Flodén, T., 1975. Seismic refraction soundings in the area around Gotland, central Baltic. Stockholm Contributions in Geology, 28: 9-43.

Flodén, T., 1980. Seismic stratigraphy and bedrock geology of the Central Baltic. Stockholm Contributions in Geology, 35: 1-240.
Flodén, T., Brännström, B, 1965. En thumperprofil genom Landsortdjupet. Geologiska Föreningens i Stockholm Förhandlingar, 87: 337-346.

Flodén, T., Puura, V., Söderberg, P., Tuuling, I., Suuroja, K., 1994. The Ordovician-Silurian transition beds in the seafloor between Gotland and Hiiumaa islands, Baltic Proper. Proceedings of the Estonian Academy of Sciences, Geology, 43: 1-17.

Flodén, T., Bjerkéus, M., Tuuling, I., Eriksson, M., 2001. A reefal succession in the Gotland area, Baltic Sea. GFF, 123: 137-152.

Gee, D.G., Stephenson, R.A., 2006. The European lithosphere: an introduction. Geological Society Memoirs, 32: 1-9.

Grahn, Y., 1995. Lower Silurian Chitinozoa and biostratigraphy of subsurface Gotland. GFF, 117: 57-65.

Grahn, Y, Nölvak, J., 2010. Swedish Ordovician Chitinozoa and biostratigraphy: a review and new data. Palaeontographica, Abteilung B: Palaeobotany - Palaeophytology, 283: 5-71.

Green, P.F., Lidmar-Bergström, K., Japsen, P., Bonow, J.M., Chalmers, J.A., 2013. Stratigraphic landscape analysis, thermochronology and the episodic development of elevated, passive continental margins. Geological Survey of Denmark and Greenland Bulletin, 30: 1-150.

Hagenfeldt, S.E., 1994. The Cambrian File Haidar and Borgholm Formations in the central Baltic and south central Sweden. Stockholm Contributions in Geology, 43: 69-110.

Hagenfeldt, S., 1997. Lower Palaeozoic acritarchs as indicators of heat flow and burial depth of sedimentary sequences of Scandinavia. Acta Universitatis Carolinae Geologica, 40: 413-424.

Hede, J.E., 1960. The Silurian of Gotland. In: The Lower Palaeozoic of Scania. The Silurian of Gotland. International Geological Congress XXI. Session Norden. Guidebook d, Sweden (eds. G. Regnéll and J.E. Hede): 44-89. Stockholm.

Hedström, H., 1923. Remarks on some fossils from the diamond boring at the Visby cement factory. Sveriges Geologiska Undersökning, Serie C, 314: 1-27.

Hobbs, B.E., Means, W.D., Williams, P.F., 1976. An Outline of Structural Geology. John Wiley \& Sons, Inc., New York.

Högdahl, K.,'Sjöström, H., Bergman, S., 2009. Ductile shear zones related to crustal shortening and domain boundary evolution in the central Fennoscandian Shield. Tectonics, 28, TC1003: 1-18.

Jaanusson, V., 1973. Aspects of carbonate sedimentation in the Ordovician of Baltoscandia. Lethaia, 6: 11-34. 
Jaanusson, V., 1976. Faunal dynamics in the Middle-Ordovician (Viruan) of Balto-Scandia. In: The Ordovician system: Proceedings of a Paleontological Association Symposium (ed. M.G Bassett): 301-326. Univ. Cardiff Press, Cardiff.

Japsen, P., Chalmers, J.A., 2000. Neogene uplift and tectonics around the North Atlantic: overview. Global and Planetary Change, 24: 165-173.

Jeppsson, L., Viira, V., Männik, P., 1994. Silurian conodont-based correlations between Gotland (Sweden) and Saaremaa (Estonia). Geological Magazine, 131: 201-218.

Jeppsson, L., Eriksson, M.E., Calner, M., 2006. A latest Llandovery to latest Ludlow high resolution biostratigraphy based on the Silurian on Gotland - a summary. GFF, 128 109-114.

Johanson, K.M., Johanson, A.M., 2003. Mechanical analysis of the geometry of the forced folds. Journal of Structural Geology, 24: $401-410$

Kaljo, D., ed., 1970. The Silurian of Estonia (in Russian with English summary). Academy of Sciences of the Estonian SSR, Tallinn.

Kaljo, D., ed., 1977. Facies and fauna of the Baltic Silurian (in Russian with English abstracts). Academy of Sciences of the Estonian SSR, Tallinn.

Kaljo, D., Nestor, H., Einasto, R., 1991. Aspects of Silurian carbonate platform sedimentation. Special Papers in Palaeontology, 44: 205-224.

Kattai, V., Vingisaar, P., 1980. Structure of the Ahtme tectonic disturbance (in Russian with English summary). Proceeding of the Academy of Sciences ESSR. Geology, 29: 55-62.

Kirs, J., Puura, V., Soesoo, A., Klein, V., Konsa, M., Koppelmaa, H., Niin, M., Urtson, K., 2009. The crystalline basement of Estonia: rock complexes of the Palaeoproterozoic Orosirian and Statherian and Mesoproterozoic Calymmian periods, and regional correlations. Estonian Journal of Earth Sciences, 58: 219-228.

Kirsimäe, K., Jørgensen, P., Kalm, V., 1999. Low-temperature diagenetic illite-smectite in Lower Cambrian clays in North Estonia. Clay Minerals, 34: 151-163.

Krzywiec, P., Kramarska, R., Zientara, P., 2003. Strike-slip tectonic within the SW Baltic Sea and its relationship to the inversion of the Mid-Polish trough - evidence from high-resolution seismic data. Tectonophysics, 373: 93-105.

Larsson, S.A.., Tullborg, E.-L., Cederbom, C., Stiberg, J.-P., 1999. Sveconorwegian and Caledonian foreland basins in the Baltic shield revealed by fission-track thermochronology. Terra Nova 11: $210-215$.

Lidmar-Bergström, K., 1999. Uplift histories revealed by landforms of the Scandinavian domes. Geological Society Special Publications, 162: 85-91.

Lidmar-Bergström, K., Näslund, J.O., 2002. Landforms and uplift in Scandinavia. Geological Society Special Publications, 196 103-116.

Lidmar-Bergström, K., Bonow, J.M., Japsen, P., 2013. Stratigraphic Landscape Analysis and geomorphological paradigms: Scandinavia as an example of Phanerozoic uplift and subsidence. Global and Planetary Change, 100: 153-171.

Loydell, D.K., Kaljo, D., Männik, P., $1998 . \quad$ Integrated biostratigraphy of the lower Silurian of the Ohesaare core Saaremaa, Estonia. Geological Magazine, 135: 769-783.

Marshak, S., Paulsen, T., 1997. Structural style, regional distribution, and seismic implications of Midcontinent Fault-and-Fold zones, United States. Seismological Research Letters, 68 511-520.

Marshak, S., Nelson, W.J., McBride J.J., 2003. Phanerozoic strike-slip faulting in the continental interior platform of the United States: examples from the Laramide Orogen, Midcontinent, and Ancestral Rocky Mountains. Geological Society Special Publications, 210: 159-184

Martinsson, A., 1956. Neue Funde kambrischer Gänge und ordovizischer Geschiebe im südwestlichen Finland. Bulletin of the Geological Institutions of the University of Uppsala, 36: 79-105.
Martinsson, A., 1958. The submarine morphology of the Baltic Cambro-Silurian area. Bulletion of the Geological Institutions of the University of Uppsala, 38: 11-35.

Martinsson, A., 1968. The Ordovician-Silurian hiatus below Gotland. Geologiska Föreningens i Stockholms Förhandlingar, 90: 561-563.

Männil, R., 1966. Evolution of the Baltic Basin during the Ordovician (in Russian with English summary). Inst. of Geology, Estonian Academy of Sciences, Tallinn.

Mertanen, S., Airo, M.-L., Elminen, T., Niemelä, R., Pajunen, M., Wasenius, P., Wennerström, M., 2008. Paleomagnetic evidence for Mesoproterozoic-Paleozoic reactivation of the Paleoproterozoic crust in southern Finland. Geological Survey of Finland, Special Paper, 47: 215-252.

Munnecke, A., Servais, T., Vachard, T., 2000. A new family of calcareous microfossils from the Silurian of Gotland in Sweden. Paleontology, 43: 1153-1172.

Munthe, H., Hede, E.J., von Post, L., 1925. Gotlands geologi en översikt. Sveriges Geologicka Undersökning, Serie C, 331: $1-130$.

Murchison, R.I., 1844. Über die allgemeinen Beziehungen zwischen die älteren paleozoischen Sedimenten in Skandinavien und den Baltischen Provinzen Russlands. Verhandlungen der Russisch-Kaiserlich Mineralogischen Gesellschaft: 90-216.

Murell, G.R., 2003. The long-term thermal evolution of central Fennoscandia, revealed by low-temperature thermochronometry. Ph.D. thesis, Vrije Universiteit Amsterdam.

Nestor, H., 1995. Ordovician and Silurian reefs in the Baltic area. Publications Service Géologique, Luxembourg, 29: 39-47.

Nestor, H., Einasto, R., 1997. Ordovician and Silurian carbonate sedimentary basin. In: Geology and Mineral Resources of Estonia (eds. A. Raukas and A. Teedumäe): 192-195. Estonian Academy Publishers, Tallinn

Nielsen, A.T., Schovsbo, N.H., 2011. The Lower Cambrian of Scandinavia: depositional environment, sequence stratigraphy and paleogeography. Earth-Science Reviews, 107: 207-310.

Noormets, R., Flodén, T., 2002. Glacial deposits and ice-sheet dynamics in the north-central Baltic Sea during the last deglaciation. Boreas, 31: 362-377.

Ostrovsky, A.A., 1995. Zona drevnego riftoobrazovaniya pod Baltiiskim Morem. Doklady Akademii Nauk, 342: 680-685

Overeem, I., Weltje, G.J., Bishop-Kay, C., Kroonenberg, S., 2001. The late Cenozoic Eridanos delta system in the Southern North Sea Basin: a climate signal in sediment supply? Basin Research, 13: 293-312.

Owen, A.W., Bruton, D.L., Bockelie, J.F., Bockelie, T.G., 1990 The Ordovician successions of the Oslo Region, Norway. Norges Geologiske Undersřkelse, Special Publication, 4: 3-54.

Pinet, N., 2016. Far-field effects of Appalachian orogenesis: a view from the craton. Geology, 44: 83-86.

Preeden, U., Plado, J., Mertanen, S., Puura, V., 2008. Multiply remagnetized Silurian carbonate sequence in Estonia. Estonian Journal of Earth Sciences, 57: 170-180.

Preeden, U., Mertanen, S., Elminen, T., Plado, J., 2009. Secondary magnetizations in shear and fault zones in southern Finland. Tectonophysics, 479: 203-213.

Puura, V., 1980. K problemam kaynozoyskoy tektoniki i formirovaniya rechnoy seti $\vee$ Baltoskandii (in Russian). In Paleotektonika Pribaltiki i Belorussii (ed. A. Raukas): 77-81. Academy of Sciences, Tallinn.

Puura, V., Flodén, T., 1997. The Baltic Sea drainage basin - a model of Cenozoic morphostructure reflecting the early Precambrian crustal pattern. Sveriges Geologiska Undersökning, Ca 86: 131-137

Puura, V., Mardla, A., 1972. The structural dissection of the sedimentary cover of Estonia (in Russian with English summary). Proceedings of the Academy of Sciences of the ESSR. Chemistry and Geology, 21: 71-77.

Puura, V., Plado, J., 2005. Settings of meteorite impact structures in the Svecofennian Crustal Domain. In: Impact Tectonics (eds. 
C. Koeberl and H. Henkel): 211-245. Springer, Berlin, Heidelberg, New York.

Puura, V., Suuroja, K., 1984. The structure of the Vihterpalu fault zone in north-western Estonia. Proceedings of the Academy of Sciences of the ESSR. Geology, 33: 33-35.

Puura, V., Vaher, R., 1997. Cover structure. In: Geology and Mineral Resources of Estonia (eds. A. Raukas and A. Teedumäe): 167-177. Estonian Academy Publishers, Tallinn.

Puura, V., Amantov, A., Tikhomirov, V., Laitakari, I., 1996. Latest events affecting the Precambrian basement, Gulf of Finland and surrounding areas. Geological Survey of Finland, Special Paper, 21: 115-125.

Puura, V., Vaher, R., Tuuling, I., 1999. Pre-Devonian landscape of the Baltic Oil-Shale Basin, NW of the Russian platform. Geological Society Special Publications, 162: 75-83.

Schmidt, C.J., Genovese, P.W., Chase, R.B., 1993. Role of basement fabric and cover-rock lithology on the geometry and kinematics of twelve folds in the Rocky Mountain foreland. GSASpecial Paper, 280: 1-45.

Schmidt, F., 1859. Beitrag zur Geologie der Insel Gotland, nebst einigen Bemerkungen über die untersilurische Formation des Festlandes von Schweden und die Heimat der norddeutschen silurischen Geschiebe. Archiv für die Naturkunde Liv-, Est- u. Kurlands, Ser. I, Bd. 2, lief. 2: 403-464.

Schmidt, F., 1881. Revision der ostbaltischen silurischen Trilobiten nebst geognostischer Übersicht des ostbaltischen Silurgebiets. Abteilung I. Mémoires de l'Academie Imperiale des Sciences de St. Petersburg. Sér. VII, 30: 1-238.

Sildvee, H., Vaher, R., 1995. Geologic structure and seismicity of Estonia. Proceedings Estonian Academy of Sciences, Geology, 44: 1525.

Smethurst, M.A., Khramov, A.N., Pisarevsky, S.A., 1998. Paleomagnetism of the Lower Ordovician orthoceras limestone, St Petersburg: a revised drift history for Baltica in the Early $\mathrm{Pa}$ leozoic. Geophysical Journal International, 133: 44-56.

Soesoo, A., Puura, V., Kirs, J., Petersell, V., Niin, M., All, T., 2004 Outlines of the Precambrian basement of Estonia. Proceedings of the Estonian Academy of Sciences, Geology, 53: 149-164.

Sopher, D., Erlström, M., Bell, N., Juhlin, C., 2016. The structure and stratigraphy of the sedimentary succession in the Swedish sector of the Baltic basin: New insights from vintage 2D marine seismic data. Tectonophysics, 676: 90-111.

Söderberg, P., 1993. Seismic stratigraphy, tectonic and gas migration in the Åland Sea, northern Baltic Proper. Stockholm Contributions in Geology, 43: 1-67.

Stearns, D.W., 1978. Faulting and forced folding in the Rocky Mountains foreland. GSA Memoirs, 151: 1-38.

Stouge, S., 2004. Ordovician siliciclastics and carbonates of Öland, Sweden. Erlanger Geologische Abhandlungen, Sonderband, 5: 91-111.

Suveizdis, P., ed., 1979. Baltic Tectonics (in Russian with English summary): 1-92. Vilnius, Mosklas.

Šliaupa, S., Hoth, P., 2011. Geological Evolution and Resources of the Baltic Sea Area from the Precambrian to the Quaternary. In: The Baltic Sea Basin (eds. J. Harff, S. Björck and P. Hoth): 13-53. Springer, Berlin.

Tammekann, A., 1940. The Baltic Glint. A Geomorphological Study. Eesti Loodusteaduste Arhiiv. Ser. I, 11: 1-103.

Thorslund, P., 1958. Djupborrningen på Gotska Sandön. Geologiska Föreningens i Stockholm Förhandlingar, 80: 190-197.

Thorslund, P., Westergård, A.H., 1938. Deep boring through the Cambro-Silurian at File Haidar, Gotland. Sveriges Geologiska Undersökning, Ser. C, 415: 5-56.

Torsvik, T.H., Cocks, L.R.M., 2013. New global palaeo-geographical reconstructions for the Early Palaeozoic and their generation. Geological Society Memoirs, 38: 5-24.

Torsvik, T.H., Rehnström, E.F., 2003. The Tornquist Sea and Baltica-Avalonia docking. Tectonophysics, 362: 67-82.

Torsvik, T.H., Van der Voo, R., Preeden, U., MacNiocaill, C., Steinberger, B., Doubrovine, P.V., Van Hinsbergen, D.J.J.,
Domeir. M., Gaina, C., Tohver, E., Meert, J.G., McCausland, P.J.A., Cocks, R.M., 2012. Phanerozoic polar wander, paleogeography and dynamics. Earth-Science Reviews, 114: 325-368.

Torvela, T., Mänttäri, I., Hermansson, T., 2008. Timing of deformation phases within the South Finland shear zone, SW Finland. Precambrian Research, 160: 277-297.

Tuuling, I., 1988. The structure of the eastern part of the Baltic Oil Shale and Phosphorite Basin (in Russian with English summary). Proceedings of the Academy of Sciences of the Estonian SSR, 37: 56-69.

Tuuling, I., Flodén, T., 2000a. Late Ordovician carbonate buildups and erosional features northeast of Gotland, northern Baltic Sea. GFF, 122: 237-249.

Tuuling, I., Flodén, T., 2000b. Baltic-Bothnian mobile zone, its geological evidences and role in formation of the sedimentary bedrock succession in the northern Baltic. The Sixth Marine Geological Conference "The Baltic", March 7-9, 2000, Hirtshals, Danmark: 85.

Tuuling, I., Flodén, T., 2001. Structure and relief of the bedrock sequence of the northern Baltic Proper. GFF, 123: 35-49.

Tuuling, I., Flodén, T., 2007. The Ordovician-Silurian boundary beds between Saaremaa and Gotland, Baltic Sea, based on high resolution seismic data. Geological Quarterly, 51 (3): 217-229.

Tuuling, I., Flodén, T., 2009a. Seismic correlation of Palaeozoic rocks across the northern Baltic Proper - Swedish-Estonian project since 1990, a review. Estonian Journal of Earth Sciences, 58: 273-285.

Tuuling, I., Flodén, T., 2009b. The Llandovery-lowermost Wenlock sequence in the Baltic Sea between Saaremaa and Gotland; subdivision, thicknesses and correlation, based on marine seismic studies. Marine Geology, 267: 55-70.

Tuuling, I., Flodén, T., 2011. Seismic stratigraphy, architecture and outcrop pattern of the Wenlock-Pridoli sequence offshore Saaremaa, Baltic Sea. Marine Geology, 281: 14-26.

Tuuling, I., Flodén, T., 2013. Silurian reefs offshore Saaremaa and their extension towards Gotland, central Baltic Sea. Geological Magazine, 150: 923-936.

Tuuling, I., Flodén, T., 2016. The Baltic Klint beneath the central Baltic Sea and its comparison with the North Estonian Klint. Geomorphology, 263: 1-18.

Tuuling, I., Flodén, T., Puura, V., Söderberg, P., 1995. Cambro-Silurian structures of the northern Baltic Proper - preliminary interpretation from high resolution seismic data. Prace Państwowego Instytutu Geologicznego, 149: 26-34.

Tuuling, I., Flodén, T., Sjöberg, J., 1997. Seismic correlation of the Cambrian sequence between Gotland and Hiiumaa in the Baltic Sea. GFF, 119: 45-54.

Väisänen, M., Skyttä, P., 2007. Late Svecofennian shear zones in southwestern Finland. GFF, 129: 55-64.

Van der Pluijm, B.A., Craddock, J.P, Graham, B.R., Harris, J.H., 1997. Paleostress in cratonic North America: Implication for deformation of continental interiors. Science, 277: 794-796.

Wannäs, K.O., 1989. Seismic stratigraphy and tectonic development of the Upper Proterozoic to Lower Paleozoic of the Bothnian Bay, Baltic Sea. Stockholm Contributions in Geology, 40: 83-168.

Wennerström, M., Airo, M.-L., Elminen, T., Niemelä, R., Pajunen, M., Vaarma, M., Wasenius, P., 2008. Orientation and properties of jointing in Helsinki area, southern Finland. Geological Survey of Finland, Special Paper, 47: 253-282.

Westergård, A.H., 1944. Borrningar genom alunskifferlagret på Öland och i Östergötland 1943. Sveriges Geologiska Undersökning, Serie C, 463, Årsbok 38: 1-22.

Westergård, A.H., 1947. Nya data rörande alunskifferlagret pí Öland. Sveriges Geologiska Undersökning, Serie C, 483, Årsbok 41: 1-12.

Winterhalter, B., Flodén, T., Ignatius, H., Axberg, S., 1981. Geology of the Baltic Sea. Elsevier Oceanography Series, 30: 1-121. 